\title{
SEASONAL DYNAMIC PATTERN ANALYSIS IN SERVICE OF CLIMATE CHANGE RESEARCH A METHODICAL CASE-STUDY - MONITORING AND SIMULATION BASED ON AN AQUATIC INSECT COMMUNITY
}

\author{
L. HUFNAGEL* - M. GAÁL \\ *e-mail: levente.hufnagel@uni-corvinus.hu \\ Department of Mathematics and Informatics, Corvinus University of Budapest, \\ H-1118 Budapest, Villányi út 29-43, Hungary \\ Phone: +36-1-482-6181, fax: +36-1-466-9273 \\ *Corresponding author \\ (Received $1^{\text {st }}$ Jan 2004, accepted $28^{\text {th }}$ June 2005)
}

\begin{abstract}
Our aim was to approach an important and well-investigable phenomenon - connected to a relatively simple but real field situation - in such a way, that the results of field observations could be directly comparable with the predictions of a simulation model-system which uses a simple mathematical apparatus and to simultaneously gain such a hypothesis-system, which creates the theoretical opportunity for a later experimental series of studies. As a phenomenon of the study, we chose the seasonal coenological changes of aquatic and semiaquatic Heteroptera community. Based on the observed data, we developed such an ecological model-system, which is suitable for generating realistic patterns highly resembling to the observed temporal patterns, and by the help of which predictions can be given to alternative situations of climatic circumstances not experienced before (e.g. climate changes), and furthermore; which can simulate experimental circumstances. The stable coenological state-plane, which was constructed based on the principle of indirect ordination is suitable for unified handling of data series of monitoring and simulation, and also fits for their comparison. On the state-plane, such deviations of empirical and model-generated data can be observed and analysed, which could otherwise remain hidden.
\end{abstract}

Keywords: state-planes, NMDS, ordination, seasonality, Heteroptera, similarity patterns

\section{Introduction and objectives}

Discovering the structure and operational mechanisms of aquatic communities and exploring the basic pattern generating processes is a scientific task standing in the frontline of ecological research; it has an extraordinary significance both from the aspect of basic and applied research. Thorough knowledge of the temporary state and the changes occurring in our environment is inevitable to prudently coordinate our society-level activities. Examining the state of living communities which the Biosphere contains, tracing the changes in their state (monitoring), evaluating data structures and researching the affecting factors standing behind ecological patterns can be mentioned among the most important objectives from the aspect of the long-term interests of human society [105].

Concerning the methodical and methodological trends of ecological research, three main approaches can be distinguished.

Field ecologists who start from the observation of real natural processes are striving during their examinations to cause the less disturbation to these processes $[94,115,159$, 176]. Their task is the prejudication-free description of synbiological patterns and in the possession of these precise descriptions (data series and tables) they try to explore the affecting factors (or to be more precise: their background patterns) generating the observed patterns. To achieve this, they generally apply the multivariate data-structure 
explorative methods and other, often used canonical methods of pattern exploration [171, 152]. The most significant theoretical description of this methodology is attributed - even by international comparison - to the works of Juhász-Nagy $[88,89,90]$ and his followers.

Another school of ecological research does not concentrate on the complex description of natural processes, but stands a hypothesis connected to a selected part-phenomenon or a hypothesis-system consisting of some alternative hypotheses to the focus. The point of these works is to test the differentiating predictions of hypotheses - often during firmly controlled, manipulative experiments. In the evaluation of these experiments, the traditional possibilities of trial statistics and variance analysis are exploited [45, 139]. Often cited classics of ,anglo-saxon ecology" followed this way in many cases [147].

The third main trend is represented by modelling (theoretical) ecologists who - in the possession of well-described basic biological phenomena and with the application of the most possible hypotheses - construct a very precise mathematical description (model) of the simplest theory concerning the observed phenomenon. The point of this methodology can be described as a logic cycle, which consists of testing (confronting the model with case studies) and developing (upgrading and re-constructing) the model. By applying this methodology, more and more realistic theory of the observed phenomenon can be gained, but in the initial stage of the work only a fragment of the available knowledge is used. The leading studies and handbooks of exact theoretical ecology use ecological modelsystems as main guidelines, the results of the other two approaches mentioned above are used in many cases only as illustrations. However, the constructed models available these days are quite far from the observed results of field ecologists [87].

All three approaches detailed above have some obvious advantages and disadvantages. Reliable, prudently checked and justified knowledge can be obtained most easily by evaluating experimental situations. But very often the criteria of prudent checking either excessively narrows the valid circle of the statement or limits the complexity of the phenomena which can be examined this way. By the help of this methodology, such results can be obtained relatively easily which are justified professionally at quite high quality, however these are of low heuristic power and far from practical availability. Thus, correct observation and detailed description is inevitable for studying complex and from pratical aspect potentially important - phenomena, since it is impossible to draw realistic hypotheses without reliable basic data. Problem is that field ecology studies which try to examine communities existing among or close to natural circumstances in complex approach, are forced to stay at gaining basic data or - at most - exploring simple correlations, because during reasoning such complicated hypotheses should be drawn, by which testing would prove to be an absolutely hopeless effort. By reasonal examination of complex phenomena, the description of hypotheses in simulation models can not be avoided, since without them we wouldn't be able to predictively differentiate between alternative explanations. Another advantage of simulation technique is that it reflects those interpretational errors, which can be disregarded even at the stage of unifying those part-theories which are separately justified or at the stage of statistical evaluation.

Ecology, as a separate field of science was named by Haeckel in 1866, but at that time he meant to a some extent different discipline under this name: a physiological field of studies which examines the connection of living organisms and their environment - source: [109]. However, it has to be admitted, that a bit later he also formed a more sophisticated opinion:

„By ecology we mean the body of knowledge concerning the economy of nature - the investigation of the total relations of the animal both to its inorganic and to its organic 
environment; including, above all, its friendly and inimical relations with those animals and plants with which it comes directly or indirectly into contact - in a word, ecology is the study of all those complex interrelations referred to by Darwin as the conditions of the struggle for existence" (Ernst Haeckel 1870, source: [1]).

Basics of supraindividual biology - which in todays professional term is now regarded as „ecology” - were laid down in the works of Clements [34, 35], Voltera [199, 200], Lotka [104], Elton [42], Gause [52], Lindeman [101, 102], and Allee [1, 2, $3]$, in the first half of the $20^{\text {th }}$ century. In the early works, results of the three methodical ways detailed above were present supporting each other, and in unity. However, the three roots of the different methodical schools existed even at the dawn of ecology, so none of them can be considered as older or newer than the others.

According to the corporal point of view of the Ecological Committee of the Hungarian Academy of Science, ecology:

„, has the task to research those limiting (...) phenomena and prosesses (...), which directly control the behaviour and spatial-temporal quantitative distribution of populations and their communities." [5].

So the corporal point of view leaves the methodical problem open. Up to now, this methodical specialization has grown to such an extent, that the representatives of the different ecological schools often can not even comprehend each others works and they group in separate organisations, publish in different papers and use substantially different terms.

Specialist field researchers often have the opinion that taxonomical and faunistical exploration of nearly natural communities (but even agro-ecosystems and other monocultures as well) is at such a low level, that forming of operational hypotheses or models makes completely no sense. According to them, many decades have to pass until data collecting and description can be exceeded. Followers of the experimental methodology think however, that serious scientific research can be conducted only in the case if there is a clear "professional hypothesis" before the start of the work. If this is the only way, we should examine even dramatically simplified experimental situations, but we have to strive to gain scientifically proven knowledge. Many modelling ecologists ("strategic modellists" or "theoretical ecologists") tries to get a grasp on basic phenomena and to study the theoretical possibilities. According to them, the development of the methodology of ecological modelling is the most important step. "Tactical modellists" or "applied ecologists" concentrate exclusively on the prognostical usefulness of the model, and they do not even care about comprehensibility (biological interpretability of mathematical expressions) of the models.

Although the above-mentioned theories are seemingly fundamentally contradictory to each other, each of them is logical in itself, and in its right place acceptable.

During our research which led to this current work, our aim was to try to approach an important and well-studiable phenomenon - connected to a relatively simple but real field situation - in such a way, that the results of field observations could be directly compared with the predictions of a simulational model-system which uses a simple mathematical apparatus and, simultaneously gaining such a hypothesis-system, which creates the theoretical opportunity for a later experimental series of studies.

Our opinion is that it is worth dealing with the approach of the three methodical schools during real case studies - even if the initial research results are obviously less detailed from the point of describing, less developed from the aspect of modelling and less controlled compared to experimental methodology - since working out of a unified methodical framework can be expected only from series of real case studies. 
For the purpose of the above-mentioned methodical case study, we chose - based on detailed comparative pre-examinations $[62,64,65,66,74]$ - a section with the most stable water level of the Szilas stream at Budapest. This part of the stream can be found right under Lake Naplás, its basin is dug and grassed, and the surrounding transect of the basin has nearly natural flora. As a phenomenon of the study, we chose the seasonal coenological changes of aquatic and semiaquatic community of Heteroptera species. During pre-examinations the Szilas stream and its side-waters were from their source to destination thoroughly surveyed and preliminary examinations have been made. In the text of the current work, the expression "Szilas stream" means exclusively the section marked for detailed studies and its state between 1991 and 2002.

For a phenomenon to study, we chose the seasonal coenological changes in the state of the aquatic and semiaquatic Heteroptera community.

Direct objectives of our work in accordance with the above-mentioned facts can be summarized as follows.

1. Working out of such a methodical case study, which synthetises, tests and develops the field- and simulational methods suitable for investigating the seasonal changes of aquatic communities.

2. Description of the seasonal changes of the Heteroptera community and exploration of the main principles of the process on the observed section of Szilas stream.

3. Developing such an ecological model-system, which is suitable for generating realistic patterns highly resembling to the observed temporal patterns, and by the help of which predictions can be given to alternative situations of climatic circumstances not experienced before (e. g. climatic changes), and furthermore which can simulate experimental circumstances.

\section{Review of literature}

The research of aquatic and semiaquatic Heteroptera has a significant history in Hungary from the beginning of the XX. century to our days but the publications are mainly taxonomic and faunistical issues. We know very little about these species from ecological and zoocoenological aspects, however recently complex ecosystem observations took place in some of their biotops [189]. These before-mentioned facts even in themselves would underline the importance of such examinations. In addition, some publications mention that in certain aquatic habitats these animals might have outstanding ecological significance simply due to their quantitative proportions [120]. But maybe even more important is the fact that the majority of them are predators, so they are near to the end of the foodchain of aquatic communities [9]. Such living organisms - based on numerous experiences - could be relatively sensitive for even tiny or (for us) hidden changes in their environment. These attributes render them especially suitable for (following the principle of bio-indication) tracing the changes in their environment and to gather important information on their habitats [72, 73]. Besides, certain aquatic Heteroptera species bear huge economical significance being fish pests and/or fish feed. Moreover, the possible role of some semiaquatic species in public health [117] and plant protection [158] can be also interesting.

One of the most important pattern-generating factor of the moderate climate nearly natural ecosystems is seasonality and the seasonal dynamism of the community structure which follows it. Based on database findings of the National Light-Trap Network for Plant Protection and Forestry seasonal dynamism hides the pattern generating role of 
the spatial differences in habitats and also of the so-called interannual effects [70, 71, $129,126]$, which means that seasonal differences on the same collection spot in the same year are much greater than that can be generally perceived on the same aspects of different years on different Hungarian habitats. Results of Schmera [167, 168] also prove this, who examined the flying activity patterns of a selected Trichoptera species and couldn't find great differences between the sampling spots. Patterns were synchronized but significant differences could be observed between months. Work of Ayre $\&$ Lamb [7] support the theory of lesser significance of annuality.

In aquatic ecosystems, the connection of seasonality and eutrophisation has been examined mainly from system-ecological aspect [57].

\section{Seasonal dynamic examinations of Heteroptera communities in aquatic habitats}

Regrettably, both domestic and international literature lack works which analysed the seasonal dynamic patterns of coenologic state changes of aquatic Heteroptera communities. However, basic data bearing information on seasonal appearance patterns of aquatic Heteroptera or dealing with seasonal part-phenomena or seasonal characteristics of certain species are available. The most detailed general ecological summaries can be found in the works of Savage [162, 163, 164, 166] and Møller-Andersen [121] for the WesternEuropean species. By studying these works, a picture from the main disciplines generally characteristic to Gerro- and Nepomorphans can be gained. There can be found basic data suitable for coenological and seasonal dynamic analysis in the work of Green [53] from the macroinvertebrata (even Heteroptera) fauna of three Great-Britain ponds, however, the paper does not deal with the interpretation of patterns.

There are many publications dealing with different bioindicational issues, thus indirectly pointing on factors and phenomena influencing seasonal patterns. There are also known for a long time such kind of efforts, which try to describe individual habitats by aquatic and semiaquatic Heteroptera communities. Among others, Fairbairn [46], Spence [177, 178, 179], Nummelin \& al. [127], Vepsäläinen \& Nummelin [198], Oscarson [131] and Vásárhelyi [191] also deals with habitat selection. Connecions between habitat, population structure and seasonality are examined in the [202] work of Zimmermann through the life-cycle of the semiaquatic Heteroptera named Mesovelia furcata which also lives in Hungary. Similar examinations has been conducted by Brönmark \& al. [29] on the Velia species in Swedish streams. Macan [106] indicated correlation among species composition of the aquatic Heteroptera, certain chemical parameters of lakes and the quantity of coastal vegetation. Savage \& Pratt [165] in an early study couldn't find any correlation among certain chemical parameters and aquatic Heteroptera communities. Later, however, significant influence of water conductivity has been pointed out [161, 162]. The $\mathrm{pH}$ of the water has also a determining effect on the species composition of the aquatic Heteroptera communities [44]. Effects of $\mathrm{pH}$ and temperature are evaluated in the 1996 paper of Blacchi \& al. based on faunistical data series on aquatic and semiaquatic Heteroptera living in Italy. Macan [107] found tight correlation between the quantity of organic matter accumulating in lakes and the aquatic Heteroptera species and communities. Bröring \& Niedringhaus $[30,31]$ pointed out correlation between the type of the examined lakes and the Heteroptera species which can be found in them. In recent times multivariate statistical methods were also applied in the exploration of the structure of aquatic and semiaquatic Heteroptera communities [48, 49, 50, 70, 72, 73]. These groups were found not to be quite suitable for water characteization by Eyre \& Foster [44]. 
Jansson [84] in his study indicated the role of three species belonging to subfamily Micronectinae in the water quality of Finnish lakes. Sládecek \& Sládeckova [172] worked out the saprobiological indexes of Central European Corixidae species. These are held valuable by Savage [164] for the application for water qualification purposes. Correlation of seasonal phenomena and hidrobiological features are dealt with in the works of Pandit \& al. $[135,136,137]$ concerning Indian currents and also at DuBois \& Rackouski [41] in connection with North American still-water habitats.

Numerous papers deal with the life-cycles and phenological phases of certain, individual species based on both field and laboratory examinations, however, most of them primarily concentrate on species which aren't distributed in Central Europe [33, 39, 85, $86,111,125,123,130,160]$. In the work of López \& al. [103], phenology, larval stages, certain quantitative morphological characteristcs and some water-chemical parameters of the collection sites of a Sigara species prevalent in the Iberian Peninsula have been evaluated. The study of Pajunen \& Jansson [134] measures seasonal changes of sex ratio concerning still-water Corixidae, and this paper also serves as a useful methodological work for modelling. Packauskas \& McPherson [133], McPherson [114], McPherson \& al. $[112,113]$ and Kaitala [92] conducted thorough experimental, controlled in vitro lifecycle studies.

There have been also published important studies in recent years in connection with ecophysiological mechanisms which are in the background of seasonal-dynamic patterns $[22,27,95]$. Results of this kind could prove useful later by interpreting processes or developing models.

Quite interesting, that numerous papers deal with the seasonal aspects of wing polymorphism $[4,54,170,179,201,124]$. Field data show that this characteristic should be considered by fine-tuning of models. The amazingly thorough study of Vepsäläinen [197] deals with seasonality, wing polymorphism and correlations between pigmentation and habitat, which has been conducted on Gerris species during his short visit in Hungary.

There isn't any summarising work for Hungarian species yet. Comments based on collecting experiences can be found in the works of Soós [175] and Benedek [21]. The most detailed and summarized work about Nepomorphs is undoubtedly the work of Bakonyi [9] - this study also includes coenological, phenological and population genetic chapters - however it does not deal with semiaquatic Heteroptera. Faunistical notes from the area of Hungary casually include data applied for different dates of colletction, but these can be considered generally sporadic. Data from the most thoroughly explored areas published by different authors are generally simple species lists $[10,11,12,13$, $14,23,24,25,36,47,58,59,62,64,74,173,183,186,190,192,194]$. This is because explorative faunistical studies have generally been conducted for completely different purposes, and even if there some other data emerged, there haven't been published directly. Fortunately some counter-examples can be also found $[119,120]$.

On the present level of our knowledge and available data, the „museum method" worked out by Soós [174] and further developed by Vásárhelyi [187] provides reliable information on phenological characteristics of individual domestic species. With this method, characteristics of aquatic and semiaquatic Heteroptera species have been described by Benedek [19], Benedek \& Jászai [20] and Bakonyi [9]. Based on our own field observations, predictions of the ,museum method" coincide quite well - in some cases highly above the expected level - with data from detailed quantitative measurements. 
We dealt with seasonal-dynamic patterns of Heteroptera communities in publications $[71,75,78,129,132,155,156,193]$. Seasonal-dynamic and phenologic patterns of other insects and insect communities are also detailed in some of our other publications and by working up models, the experiences of these works have been also utilized: [75, 78, 129, $132,150,193]$. We usually only cited these basic data which were used for evaluating seasonal-dynamic patterns and were published generally in faunistical notes and in our papers dealing with pattern evaluation. We reported about Heteroptera in our following data-announcing papers: $[37,38,62,63,64,65,66,67,74,183,184]$. Other publication related to Heteroptera: [76]. Basic faunistical data on other insects used for seasonal analyses are included in the following papers: [25, 40, 153, 154, 155, 156, 157].

\section{Materials and methods}

\section{The examined section of the Szilas stream as a habitat}

A most detailed definition of the characteristic features of a habitat selected for the purpose of an ecological case-study is crucial to create a firm base for comparisons with other observations carried out (maybe later) by others, on other habitats. Regrettably, exploration of domestic small water currents is at very low level (on $90 \%$ of the currents not any kind of meritable examinations have taken place until recently). Thus, in this part we could rely only on the results of the pre-examinations and some literature sources.

A decisive proportion of our field studies published in this paper has been carried out between 1991 and 2002 on a (Danube-side) section of Szilas stream, which lies next to the Naplás Lake of Budapest (former Szilas stream reservoir). The Szilas stream is a left-side tributary stream of Danube, which flows through the Pest Alluvial Plain. The area can be found on the northeastern part of Budapest, at the eastern border of the XVI. District. The relatively stable hydrological properties of the section in question are guaranteed by Naplás Lake (or the leaking of its dam). The work has been started with the practical environment protection examination series for preserving natural values of Naplás Lake and its surroundings. As a result of the series of examinations, the most valuable parts of the area became protected. The geomorphological characteristics of the landscape are determined mainly by the $400-500 \mathrm{~m}$ wide alluvium of the stream and the V. Danube terrace which is more gently sloping on the Northern and steeper on the Southern side and consist mainly from grave and sand [91, 140, 141, 169]. The Szilas stream appeared in the Pleistocene era. The flow direction of the stream was shaped to gain its present characteristics during the effects of Middle-Würm movements. At the beginning of the Holocene era, the Szilas stream formed two narow terraces, huminite molding slime being the main material of its alluvium [180].

From climatic aspect, the area can be considered as moderately warm and dry, with a slightly less than 2000 sunlight hours (1800 hours in summer and 180 in the winter). Annual average temperature is $10.0-10.2^{\circ} \mathrm{C}$, length of frost-free period varies between 188 and 219 days. Historical average of maximum temperature varies between 34.0-34.2 ${ }^{\circ} \mathrm{C}$, minimum temperature betwen $-14.5-16.5{ }^{\circ} \mathrm{C}$. Daily average temperature between April $10^{\text {th }}$ and October $19^{\text {th }}$ exceeds $+10^{\circ} \mathrm{C}$, this means $190-192$ days annually. Annual sum of precipitation is approximately $550-600 \mathrm{~mm}, 310-340 \mathrm{~mm}$ in the vegetation period. 30-33 snow-covered days are presumable, average maximum snow thickness reaches $20 \mathrm{~cm}$. Aridity index moves between 1.17 and 1.28. Most prevalent wind direction is NW, average wind speed is between $2.5-3 \mathrm{~m} / \mathrm{s}$ [110].

On the section in present study, average width of the stream is between $150-250 \mathrm{~cm}$, average depth in the current line is $8-35 \mathrm{~cm}$, with a current speed of $0.01-0.4 \mathrm{~m} / \mathrm{s}$ in the 
vegetation terminal (half year) of the examination period. Vegetation cover of the length of the bank line $40-100 \%$, and vegetation coverage of the water surface varied between $30-100 \%$, shading of the foliage above the water-course under $1 \%$. By our own measurements, $\mathrm{pH}$ of the water is between $7.8-8.3$, conductivity $0.79-1.90 \mathrm{mS} / \mathrm{cm}$, chemical oxygen demand $\left(\mathrm{KOI}_{\mathrm{Mn}}\right) 3.2-15.0 \mathrm{mg} \mathrm{O} / \mathrm{dm}^{3}$, level of dissolved oxygen $70-100 \%$, algae count $0.3-3.5 \cdot 10^{6}$ (individual $/ \mathrm{dm}^{3}$ ). We measured by coloritmetric rapid tests the nitrate concentration between $10-25 \mathrm{mg} / \mathrm{dm}^{3}$, nitrite $0.05-0.25 \mathrm{mg} / \mathrm{dm}^{3}$, phosphate $0.1-$ $0.6 \mathrm{mg} / \mathrm{dm}^{3}$. We couldn't detect ammonia with rapid test. Further chemical and hydrological data were published in [74]. From hydrobiological aspect, the water can be considered mesosaprobic, meso-eutrophic and mesohalobic.

From botanical aspect, the valley of Szilas stream lies on the border of two flora regions, Matricum and Eupannonicum. Vegetation and plant-coenological characteristics are described in the works of Borbás [28] and Rajkai [148, 149]. The vegetation of the immediate surroundings of the examined section has been described in detail by Stollmayer [180], vegetation of the water-course by Hufnagel \& Stollmayer [74]. Vegetation of the examined section is mainly characterised by Sium latifolium L., Myosotis palustris (L) Nath. em. Rchb., Mentha longifolia (L) Nath., Mentha aquatica L., Juncus inflexus L., Scirpus sylvaticus L., and Carex acutiformis Ehrh.

The fish fauna of the section has been examined by T. Erös. According to his (hitherto unpublished) data, on a large proportion of the area, fish hardly can be found. Based on his thorough examinations, in the deeper parts of the course small numbers of crucian carp (Carassius carassius), spined loach (Cobitis elongatoides complex), roach (Rutilus rutilus), European chub (Leuciscus cephalus), black bullhead (Ameiurus melas), bleak (Alburnus alburnus), European perch (Perca fluviatilis), pumpkinseed (Lepomis gibbosus) and Chinese rasbora (Pseudorazbora parva) can be found.

According to the number of individuals, $89 \%$ of the fish belong to the omnivor, $5 \%$ to insectivor-piscivor, $4 \%$ to insectivor-detritivor, $2 \%$ to insectivor feed biology group. Most prevalent species is the crucian carp.

According to literature data $[93,180]$ in the vicinity of Lake Naplás, numerous amphibious species, like smooth newt (Triturus vulgaris), crested newt (T. cristatus), firebellied toad (Bombina bombina), common tree frog (Hyla arborea), spadefoot toad (Pelobates fuscus), common and green toad (Bufo bufo, B. viridis), agile frog (Rana dalmatina), European common frog (Rana temporaria) and edible frog species group (Rana esculenta complex) can be found. This is the first published flatland occurrence of European common frog. Based on our own experiences, moorfrog (Rana arvalis) and common toad seem to be the most common. We could not observe any newts, European common frogs and common tree frogs, however, We did not conducted surveys directly on amphibious species. As for reptiles, we observed grass snake (Natrix natrix) and European pond turtle (Emys orbicularis) on one or two occasions. Stollmayer \& al. [180] gives a thorough overview about the bird fauna of the territory, however, we could not observe significant presence of water fowls on the examined section of the stream.

Between 1991 and 2002 we continuously collected data and observations about the invertebrate fauna of the examined section of stream. The most profound general zoologic exploration took place during the series of examinations in 2002. At that time, from $15^{\text {th }}$ March to $27^{\text {th }}$ October (beside the ordinary Heteroptera sampling) we also conducted regular - fortnightly done - zoocoenological sampling, which consisted of identical methods during the full length of the examination period, namely silt sampling, water netting, surface netting, grass-netting of above-surface vegetation and plankton-net 
sampling. Before the sampling process we did frog count. Our examinations only extended to the waterbed and the immediate above-surface part of the vegatation - we wilfully avoided the bench line, during grass-netting just plants leaning over the riverbed from a $10 \mathrm{~cm}$ wide zone of the coastal line could be incorporated. We considered the examination of the vegetation stretching over the waterbed very important for four reasons. At first, because certain members of the semiaquatic predator guild (e.g. Hydrometra spp., semiaquatic wolf spiders etc.) and just hatched adults of aquatic insects are very often located here. Secondly, because one of the main kind of food of the Gerris species are „land" insects accidentally fallen onto the water surface. Thirdly, because the hereby abiding net-spinning spiders are important predators of the insects flying out of the water (e.g. gnats, mayflies), and finally because the herbivore insects can exert a significant effect on the community by eating on aquatic plants.

A summarising overview on the main data of general, zoological exploration in year 2002 are shown in Table 1.

A summarising overview of the main data of the general zoological survey conducted in the spring of 2002 can be seen in Table 1. Animals are classified into morphones because taxa in themselves are less explanatory from the aspect of seasonal dynamic patterns. It can be clearly seen from the table, that the different development stages or body size categories of the same taxon show fundamentally different coenological behaviour. To achieve a uniform structure, we followed the system of Papp [138] during higher taxonomical classification, and we took the work of Móczár [118] as a base for naming morphones (at levels below families) even when we used different works for identification. Samples from the water body are given conjugated in order to achieve briefer data and transparency, because the method of collection can be generally presumed from the name of the taxon (and body size category). Numerical data given in the table can be compared row-wise, since comparison between different rows can be informative only in case of identical body-size categories.

\section{Methods of field monitoring}

We have been studying the Heteroptera community of the Szilas stream since 1991. In this study, the field data collected in 1996 are processed and evaluated. The seasonal dynamic patterns in the vegetation period (between March and November) with the greatest frequency were observed in 1994 (monthly), in 1996 (weekly) and in 2002 (fortnightly). We only collected qualitative data in 1991 and 1992. In 1993, 1995, 1998 and 1999 we sampled 3-4 times in the vegetation period. From the years of 1997, 2000 and 2001 we do not have any data. We used a method, which was designed for qualitative purposes - however being rather semi-quantitative - to explore the seasonaldynamic patterns. In the winter period we only conducted qualitative examinations.

Based on our data and observations it can be stated that in the period between 1991 and 2002 on the examined section of Szilas stream (under Lake Naplás) fundamental changes have not been occurred nor in the hydrological and vegetation characteristics, nor in the structure of the Heteroptera community.

For the purpose of our studies, we chose a $300 \mathrm{~m}$ long section of Szilas stream below the Naplás Lake. The peculiar section was chosen for its homogeneity from floral and hydrological aspects.

The coenological survey of Heteroptera consisted of the simultaneous application of two very different methods, namely a quantitative area-closing sampling and a roving hand-webbing collection. 
Table 1: Conjugated data of the fauna exploration in 2002. Italic names are so-called morphons, which had been conceived from some kind of taxonomic name and body size category (I: below $5 \mathrm{~mm}$, II: between 5-10 mm, III: above $10 \mathrm{~mm}$ ) or in case of insects, from morphological state (larva, pupa, adult etc). Table contains data from aquatic samples (typed in bold) and data gained from grass-netting the above-surface vegetation (typed in normal characters).

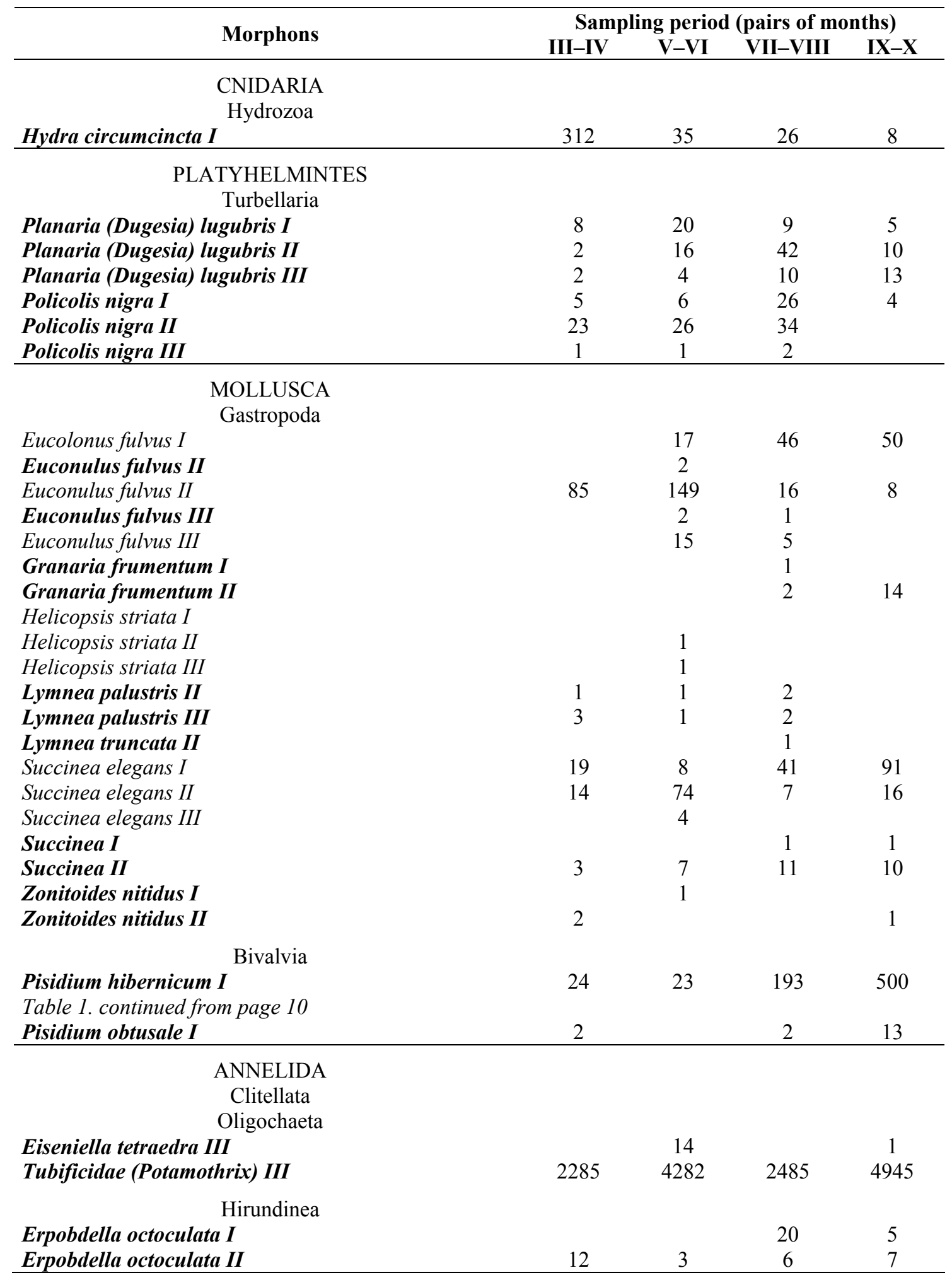




\begin{tabular}{|c|c|c|c|c|}
\hline \multirow{2}{*}{ Morphons } & \multicolumn{4}{|c|}{ Sampling period (pairs of months) } \\
\hline & III-IV & V-VI & VII-VIII & IX-X \\
\hline \multicolumn{5}{|l|}{ Hirundinea (continued) } \\
\hline Erpobdella octoculata III & 12 & 23 & 22 & 24 \\
\hline Glossiphonia complanata II & 1 & & & \\
\hline Glossiphonia complanata III & 1 & & & 1 \\
\hline \multicolumn{5}{|l|}{ ARTHROPODA } \\
\hline \multicolumn{5}{|l|}{ Arachnida } \\
\hline \multicolumn{5}{|l|}{ Araneae } \\
\hline Agriopidae I & & & 2 & \\
\hline Agriopidae I & & 1 & 5 & 7 \\
\hline Dictynidae: Dictyna arundinacea II & & & & 1 \\
\hline Lycosidae I & 3 & 5 & 18 & 2 \\
\hline Lycosidae II & 5 & & 6 & \\
\hline Lycosidae: Pardosa amentata I & 1 & & & \\
\hline Lycosidae: Pirata latinans I & & 6 & 1 & 6 \\
\hline Lycosidae: Pirata piraticus I & 3 & 1 & 52 & 14 \\
\hline Lycosidae: Pirata piraticus II & 2 & 6 & 1 & 24 \\
\hline Lycosidae: Pirata piraticus III & & 1 & & \\
\hline Pisauridae I & 5 & & 15 & 3 \\
\hline Pisauridae II & 1 & 1 & 2 & 4 \\
\hline Salticidae II & & & & 1 \\
\hline Tetragnathidae (T. extensa) I & 10 & 2 & 6 & 21 \\
\hline Tetragnathidae (T. extensa) II & & 7 & 15 & 2 \\
\hline Tetragnathidae (T. extensa) III & & & & 2 \\
\hline Tetragnathidae I & 71 & 31 & 30 & 47 \\
\hline Tetragnathidae II & 2 & 27 & 26 & 6 \\
\hline Theridae I & & & 1 & \\
\hline Theridae II & & 1 & & \\
\hline Thomisidae I & & 1 & & \\
\hline Thomisidae I & 21 & 3 & 12 & 13 \\
\hline \multicolumn{5}{|l|}{ Acari } \\
\hline Hydracarina I & 3 & 4 & 1 & 3 \\
\hline Ixodes ricinus $I$ & 3 & & & \\
\hline Ixodeus ricinus I & 1 & & & \\
\hline Oribatida I & 17 & 25 & 22 & 8 \\
\hline \multicolumn{5}{|l|}{ Malacostraca } \\
\hline \multicolumn{5}{|l|}{ Edriophthalma } \\
\hline Asellus aquaticus I & 26 & 6 & 1 & \\
\hline Asellus aquaticus II & 40 & 5 & 10 & 1 \\
\hline Gammarus roeseli I & 1591 & 3977 & 5617 & 7536 \\
\hline Gammarus roeseli II & 1473 & 6445 & 5073 & 6340 \\
\hline Gammarus roeseli III & 525 & 2007 & 2000 & 2950 \\
\hline Oniscoidea I & 1 & & & \\
\hline Oniscoidea II & 1 & 2 & & 1 \\
\hline \multicolumn{5}{|l|}{ Maxillopoda } \\
\hline \multicolumn{5}{|l|}{ Copepoda } \\
\hline Acantocyclops (?) I & 26 & 1 & & \\
\hline Acantocyclops robostus I & 317 & 1769 & 1983 & 1862 \\
\hline Eucyclops I & & 28 & 133 & 34 \\
\hline Eudiaptomus I & 14 & & & 330 \\
\hline \multicolumn{5}{|l|}{ Ostracoda } \\
\hline Heterocypris salina I & 3 & 11 & 3 & \\
\hline Limnocythere sanctipatricii I & 28 & 37 & 536 & 26 \\
\hline
\end{tabular}




\begin{tabular}{|c|c|c|c|c|}
\hline \multirow{2}{*}{ Morphons } & \multicolumn{4}{|c|}{ Sampling period (pairs of months) } \\
\hline & III-IV & V-VI & VII-VIII & $\mathbf{I X}-\mathbf{X}$ \\
\hline \multicolumn{5}{|l|}{ Phyllopoda } \\
\hline Chydorus sphaericus I & & 4 & 384 & 7 \\
\hline \multicolumn{4}{|l|}{ Parainsecta } & \\
\hline Entomobrya quinquelineata I & & 3 & 2 & 3 \\
\hline Lepidocyrtus cyaneus I & & 2 & 10 & 7 \\
\hline Lepidocyrtus paradoxus I & & 2 & 4 & 3 \\
\hline Orchesella cincta I & & & & 1 \\
\hline Podura aquatica I & 28 & 28 & 10 & 55 \\
\hline Sminthurides aquaticus I & & & & 2 \\
\hline \multicolumn{5}{|l|}{ Insecta } \\
\hline \multicolumn{5}{|l|}{ Ephemeroptera } \\
\hline Baetis I larva & 331 & 216 & 786 & 87 \\
\hline Baetis II larva & 131 & 227 & 1622 & 269 \\
\hline Baetis II adult & & 2 & & \\
\hline Baetis III larva & & 75 & & \\
\hline Cloeon larva & & 18 & & 4 \\
\hline Prosopistoma I subimago & & & & 1 \\
\hline \multicolumn{5}{|l|}{ Odonata } \\
\hline Aeschnidae:Aeschna affinis III larva & & & 2 & 1 \\
\hline Agrionidae: Ischnura elegans III adult & & 2 & & \\
\hline Agrionidae: Ischnura pumilio III larva & & 3 & 6 & \\
\hline Agrionidae: Ischnura pumilo I larva & & & 10 & 1 \\
\hline Agrionidae: Ischnura pumilo II larva & 1 & 1 & 99 & 85 \\
\hline Agrionidae: Ischnura pumilo III larva & 12 & 23 & & 168 \\
\hline Agrionidae: Coenagrion puella III adult & & 1 & & \\
\hline Agrionidae: Ischnura elegans III larva & & 2 & & 2 \\
\hline Agrionidae: Platycnemis pennipes I larva & & & 77 & \\
\hline Agrionidae: Platycnemis pennipes II larva & & & 18 & 3 \\
\hline Agrionidae: Platycnemis pennipes III larva & & 3 & 2 & 7 \\
\hline Agrionidae: Platycnemis pennipes III larva & & & 1 & \\
\hline Agrionidae: Pyrrhosma nymphula III adult & & 1 & & \\
\hline Calopterigidae: Calopteryx splendels III adult & & 1 & & \\
\hline Calopterigidae: Calopteryx splendens II larva & 1 & & & \\
\hline Calopterigidae: Calopteryx splendens III larva & 4 & & & 1 \\
\hline Libellulidae: Libellula fulva II larva & & & & 2 \\
\hline Libellulidae: Libellula quadrimaculata I larva & & 1 & & 1 \\
\hline Libellulidae: Libellula quadrimaculata II larva & & 1 & & 1 \\
\hline Libellulidae: Libellula quadrimaculata III larva & 2 & 2 & 2 & 5 \\
\hline Libellulidae: Orthetrum brunneum II larva & & & 2 & \\
\hline Libellulidae: Orthetrum brunneum III larva & & & 1 & \\
\hline Libellulidae: Orthetrum coerulescens III larva & 6 & 2 & & \\
\hline Libellulidae: Orthetrum coerulescens III larva & & & 1 & \\
\hline Plecoptera & & & & \\
\hline Nemouridae: Nemoura cinerea II adult & 108 & & & \\
\hline Nemouridae: Nemoura II larva & 258 & & & \\
\hline Ensifera & & & & \\
\hline Conocephalidae: Conocephalus fuscus IIIadult & & & 18 & \\
\hline Ephippigeridae: Ephippigera ephippiger IIIadult & & 3 & & \\
\hline Caelifera & & & & \\
\hline $\begin{array}{l}\text { Acrididae III adult } \\
\text { Acrididae. Chorthinpus narallelus IUI adult }\end{array}$ & & 3 & 18 & \\
\hline
\end{tabular}




\begin{tabular}{|c|c|c|c|c|}
\hline \multirow{2}{*}{ Morphons } & \multicolumn{4}{|c|}{ Sampling period (pairs of months) } \\
\hline & III-IV & V-VI & VII-VIII & IX-X \\
\hline \multicolumn{5}{|l|}{ Thysanoptera } \\
\hline Bolothrips cingulatus I adult & 12 & & 2 & \\
\hline Limothrips angulicornis I adult & & & & 3 \\
\hline Thrips phsapus I adult & & & 2 & \\
\hline Thysanoptera I adult & & 4 & 1 & \\
\hline \multicolumn{5}{|l|}{ Heteroptera } \\
\hline Anthocoridae: Orius laticollis I adult & 1 & & 1 & \\
\hline Corixidae: Hesperocorixa linnaei I larva & 1 & & & \\
\hline Corixidae: Hesperocorixa linnaei I adult & 1 & & & \\
\hline Corixidae: Micronecta meridionalis I larva & 5 & 7 & 2 & \\
\hline Corixidae: Micronecta meridionalis I adult & & & 2 & \\
\hline Corixidae: Sigara lateralis I adult & & & 2 & \\
\hline Corixidae: Sigara striata I adult & & 1 & & \\
\hline Gerridae: Aquarius paludum III adult & 1 & 1 & 2 & 1 \\
\hline Gerridae: Gerris argentatus I adult & & 3 & & \\
\hline Gerridae: Gerris asper II adult & 1 & & & \\
\hline Gerridae: Gerris lacustris II adult & 66 & 87 & 346 & 254 \\
\hline Gerridae: Gerris lacustris larva & & 156 & 784 & 352 \\
\hline Gerridae: Gerris odontogaster II adult & 1 & 2 & & \\
\hline Gerridae: Gerris odontogaster larva & & 1 & & \\
\hline Gerridae: Gerris thoracicus adult & 2 & 4 & 5 & \\
\hline Hydrometridae: Hydrometra stagnorum II larva & & 2 & 7 & \\
\hline Hydrometridae: Hydrometra stagnorum III adult & 2 & 12 & 13 & 5 \\
\hline Lygaeidae: Cymus glandicolor I adult & 1 & & & \\
\hline Lygaeidae: Cymus melanocephalus I adult & & 1 & & \\
\hline Lygaeidae: Raglius confusus I adult & & & 1 & \\
\hline Miridae: Adelphocoris lineolatus I adult & & & 2 & \\
\hline Miridae: Adelphocoris seticornis I adult & & & 1 & \\
\hline Miridae: Polymerus holosericeus I adult & & & 2 & \\
\hline Miridae: Stenodema calcarata I adult & 2 & & & \\
\hline Nabidae: Nabis ferus I adult & & & 2 & 1 \\
\hline Nepidae: Nepa cinerea II larva & & 27 & 62 & 1 \\
\hline Nepidae: Nepa cinerea III adult & & & 5 & 9 \\
\hline Notonectidae: Notonecta glauca II adult & & 3 & 18 & 48 \\
\hline Notonectidae: Notonecta glauca II larva & & 7 & 7 & \\
\hline Pleidae: Plea minutissima I adult & & 4 & & \\
\hline Saldidae: Saldula opacula I adult & & & 1 & \\
\hline Scutelleridae: Eurygaster maura II adult & & 2 & & \\
\hline Tingidae: Agramma confusum I adult & & & 1 & \\
\hline Tingidae: Dictyla hamuli I adult & 1 & & & \\
\hline Veliidae: Microvelia reticulata I adult & & & & 2 \\
\hline Auchenorrhyncha & & & & \\
\hline Cercopidae, Lepyronia II adult & & 1 & & \\
\hline Cercopidae, Philaenus spumarius I adult & & & 1 & \\
\hline Cercopidae, Philaenus spumarius II adult & & & & 1 \\
\hline Cercopidae: Aphrophora alni II adult & & & & 1 \\
\hline Cicadellidae : Cicadella II adult & & 1 & 2 & 3 \\
\hline Cicadellidae : Cicadula sp II adult & & & 1 & 4 \\
\hline Cicadellidae I adult & 6 & 19 & 37 & 60 \\
\hline Cicadellidae II adult & & 8 & 22 & 12 \\
\hline Cicadellidae, Edwardsiana rosae I adult & & & & 1 \\
\hline Cicadellidae, Eupteryx urticae II adult & & & & 2 \\
\hline Cicadinea I larva & & 5 & 4 & 2 \\
\hline Delphacidae I adult & & 4 & 8 & 37 \\
\hline
\end{tabular}




\begin{tabular}{|c|c|c|c|c|}
\hline \multirow{2}{*}{ Morphons } & \multicolumn{4}{|c|}{ Sampling period (pairs of months) } \\
\hline & III-IV & V-VI & VII-VIII & IX-X \\
\hline \multicolumn{5}{|l|}{ Auchenorrhyncha (continued) } \\
\hline Delphacidae II adult & & 11 & 5 & 1 \\
\hline Delphacidae: Calligypona sp I adult & & & & 1 \\
\hline Delphacidae, Dicranotropis II adult & & & 1 & \\
\hline Delphacidae, Kelisia guttala I adult & & & & 6 \\
\hline Issidae I adult & & & & 2 \\
\hline \multicolumn{5}{|l|}{ Sternorrhyncha } \\
\hline Aphidinea $I * A *$ adult & & 9 & 17 & 60 \\
\hline Aphidinea $I * B *$ adult & & & 3 & 27 \\
\hline Aphidinea I adult & & 16 & 30 & 139 \\
\hline Psyllinea I (Aphalara calthae) adult & & & 1 & \\
\hline \multicolumn{5}{|l|}{ Coleoptera } \\
\hline Anobiidae I adult & & & & 1 \\
\hline Anthicidae I adult & & & 1 & \\
\hline Anthribidae I adult & & 1 & 7 & 1 \\
\hline Bruchidae I adult & & & 4 & \\
\hline Byrrhidae I adult & & & 1 & \\
\hline Cantharidae I adult & & 2 & & \\
\hline Carabidae I adult & & & & 1 \\
\hline Carabidae II adult & & 1 & & \\
\hline Cerambicidae I adult & & & 1 & \\
\hline Cerambicidae III adult & & 1 & & \\
\hline Cerambycidae I adult & 7 & & & \\
\hline Cerambycidae II adult & & & 2 & \\
\hline Cerambycidae III adult & & 1 & & \\
\hline Chrysomelidae, Donacia semicuprea I adult & 3 & 16 & 2 & 3 \\
\hline Chrysomelidae I adult & & 8 & 7 & \\
\hline Chrysomelidae II adult & & 173 & 2 & 2 \\
\hline Coccinellidae I adult & & 1 & 8 & \\
\hline Coccinellidae I adult & 1 & 8 & 2 & \\
\hline Coccinellidae II adult & & & 1 & \\
\hline Coccinellidae II adult & & & 2 & \\
\hline Curculionidae I adult & & 3 & 2 & 4 \\
\hline Curculionidae I adult & 8 & 2 & 10 & 2 \\
\hline Curculionidae II adult & & & 2 & \\
\hline Curculionidae II adult & 4 & 8 & & \\
\hline Curculionidae III adult & & & 1 & \\
\hline Drilidae I adult & & 1 & & \\
\hline Dytiscidae I adult & & 1 & & 1 \\
\hline Dytiscidae I adult & & 3 & & 1 \\
\hline Dytiscidae III adult & & 1 & & 4 \\
\hline Dytiscidae, III larva & 1 & & 22 & 15 \\
\hline Gyrinidae II adult & & 5 & 4 & \\
\hline Haliplidae I adult & & 1 & 6 & 2 \\
\hline Helophoridae I adult & 2 & 6 & 3 & 4 \\
\hline Helophoridae I larva & & 7 & & \\
\hline Hydrophilidae I adult & 6 & 11 & 114 & 13 \\
\hline Hydrophilidae II adult & & 1 & 1 & \\
\hline Hydrophilidae III adult & & & 1 & \\
\hline Hydrophilidae/+Helophoridae/I adult & 6 & 2 & 6 & \\
\hline Lampyridae II adult & & 1 & & \\
\hline Lampyridae III adult & & 1 & & \\
\hline Lathridiidae I adult & & 1 & & \\
\hline Malachiidae II adult & & & 1 & 1 \\
\hline
\end{tabular}




\begin{tabular}{|c|c|c|c|c|}
\hline \multirow{2}{*}{ Morphons } & \multicolumn{4}{|c|}{ Sampling period (pairs of months) } \\
\hline & III-IV & $\mathbf{V}-\mathbf{V I}$ & VII-VIII & IX-X \\
\hline \multicolumn{5}{|l|}{ Coleoptera (continued) } \\
\hline Mordellidae I adult & & 1 & & \\
\hline Mordellidae I adult & & & 1 & \\
\hline Mordellidae II adult & & 2 & & \\
\hline Mycetophagidae I adult & & & 2 & \\
\hline Oedemeridae II adult & & & 1 & \\
\hline Scarabaeidae I adult & 1 & 3 & 1 & \\
\hline Scolytidae I adult & & 1 & & \\
\hline Spercheidae I adult & & & 3 & \\
\hline Staphylinidae I adult & & 2 & 3 & 2 \\
\hline Staphylinidae I adult & & 1 & 2 & 1 \\
\hline \multicolumn{5}{|l|}{ Megaloptera } \\
\hline Syalidae: Sialis fuliginosa III, adult & 2 & & & \\
\hline Syalidae: Sialis flavilatera I larva & & & 1 & \\
\hline Syalidae: Sialis flavilatera III adult & 1 & & & \\
\hline \multicolumn{5}{|l|}{ Hymenoptera } \\
\hline Agriotypidae II adult & 1 & & & \\
\hline Andreidae III adult & & & 1 & \\
\hline Aphidiidae I adult & & 1 & 2 & \\
\hline Apidae III adult & & & 1 & \\
\hline Apoidae III adult & & 1 & & \\
\hline Aulacidae I adult & & 1 & & \\
\hline Belytidae I adult & & & 1 & \\
\hline Ceraphronidae I adult & & 1 & & \\
\hline Eulophidae I adult & & & 1 & \\
\hline Formicidae I adult & & 37 & 50 & 10 \\
\hline Formicidae I adult & 7 & 43 & 52 & 3 \\
\hline Formicidae II adult & & 1 & 2 & \\
\hline Formicidae II adult & & & 2 & \\
\hline Gasteruptonidae II adult & & & 2 & \\
\hline Hybryzonidae I adult & & & 1 & \\
\hline Ichneumonidae I adult & & & 1 & \\
\hline Ichneumonidae I adult & & 1 & 12 & 16 \\
\hline Ichneumonidae II adult & 1 & 6 & 8 & 2 \\
\hline Ichneumonidae III adult & & & 1 & \\
\hline Maumaridae I adult & & 1 & & \\
\hline Orussidae I adult & & & & 1 \\
\hline Platygasteridae I adult & & & 1 & \\
\hline Scelionidae I adult & & & & 2 \\
\hline Tenthredinidae I larva & & 1 & 1 & \\
\hline Tenthredinidae II adult & & & 1 & \\
\hline Tenthredinidae I adult & & & & 3 \\
\hline Tenthredinidae II adult & 2 & 1 & 1 & \\
\hline Tenthredinidae III adult & & 5 & & \\
\hline \multicolumn{5}{|l|}{ Trichoptera } \\
\hline Hydroptilidae: Ptilocolepus granulatus I larva & 2 & & & \\
\hline Leptoceridae: Athrispodes aterrimus larva & & & 2 & \\
\hline Limnephilidae: Grammotaulius III adult & & & 3 & \\
\hline Limnephilidae: Limnephilus II larva & 340 & 115 & 10 & \\
\hline Limnephilidae: Limnephilus III adult & & & 8 & 12 \\
\hline Limnephilidae: Limnephilus III larva & 667 & 423 & 111 & \\
\hline Phryganeidae: Oligostomis III adult & & & 9 & \\
\hline
\end{tabular}




\begin{tabular}{|c|c|c|c|c|}
\hline \multirow{2}{*}{ Morphons } & \multicolumn{4}{|c|}{ Sampling period (pairs of months) } \\
\hline & III-IV & V-VI & VII-VIII & IX-X \\
\hline \multicolumn{5}{|l|}{ Lepidoptera } \\
\hline Noctuidae I adult & & 1 & 2 & 1 \\
\hline Noctuidae II adult & & 4 & 2 & \\
\hline Noctuidae III adult & & 1 & 3 & 1 \\
\hline Pyralidae I larva & & 1 & 1 & \\
\hline \multicolumn{5}{|l|}{ Diptera } \\
\hline Agriotypidae II adult & 2 & & & \\
\hline Agromyzidae I adult & & & 1 & 1 \\
\hline Annisopodidae II adult & 3 & & & \\
\hline Anthomyzidae I adult & & 2 & & \\
\hline Anthomyzidae I adult & & & 4 & \\
\hline Asilidae I adult & 12 & & & \\
\hline Asilidae I adult & & 1 & & \\
\hline Asilidae II adult & & 1 & & \\
\hline Asilidae I larva & & 2 & & \\
\hline Asteiidae I adult & & & 1 & \\
\hline Camillidae I adult & 4 & 5 & 11 & 1 \\
\hline Cecidomyiidae I adult & & 1 & 1 & 2 \\
\hline Cecidomyiidae I adult & 6 & & & 1 \\
\hline Ceratopogonidae I adult & 2 & 23 & 25 & \\
\hline Ceratopogonidae II adult & & & & 2 \\
\hline Ceratopogonidae I larva & 47 & 33 & 4 & 25 \\
\hline Ceratopogonidae II larva & & 9 & & \\
\hline Chironomidae (a) I adult & 5 & 2 & 3 & 25 \\
\hline Chironomidae (a) I larva & 243 & 1144 & 3464 & 1117 \\
\hline Chironomidae (a) I pupa & 11 & & 60 & 67 \\
\hline Chironomidae (b) II larva & 55 & 43 & 130 & 116 \\
\hline Chironomidae I adult & 14 & 3 & 20 & 151 \\
\hline Chloropidae I adult & 68 & 19 & 173 & 22 \\
\hline Choloropidae I adult & 1 & & 10 & 9 \\
\hline Conopidae III adult & 2 & & & \\
\hline Culicidae I adult & 1 & & 2 & 9 \\
\hline Culicidae II adult & & & & 2 \\
\hline Culicidae II adult & & 1 & 1 & \\
\hline Culicidae I larva & & 33 & 136 & 6 \\
\hline Culicidae II larva & 1 & 10 & 87 & 4 \\
\hline Culicidae II pupa & & 3 & 10 & 6 \\
\hline Curtonotidae I adult & & & 1 & \\
\hline Dixidae II adult & & & & 2 \\
\hline Dixidae I adult & & & 1 & \\
\hline Dixidae I larva & & & 2 & 4 \\
\hline Dolichopodidae I adult & & & 3 & 1 \\
\hline Dolichopodidae II adult & & 1 & & \\
\hline Dolichopodidae II larva & & 2 & 4 & \\
\hline Drosophilidae I adult & & 1 & 2 & \\
\hline Dryomyzidae II adult & & & 1 & \\
\hline Empididae I larva & & & 2 & 6 \\
\hline Empididae II larva & 4 & & & 2 \\
\hline Empididae II adult & & 3 & 2 & \\
\hline Empididae III adult & 1 & & & \\
\hline Empididae III adult & 3 & & & \\
\hline Ephydridae I adult & & & & 55 \\
\hline Ephydridae I larva & & & 6 & \\
\hline Ephydridae I adult & 10 & 17 & 10 & \\
\hline Helomyzidae I adult & & & 1 & 1 \\
\hline
\end{tabular}




\begin{tabular}{|c|c|c|c|c|}
\hline \multirow{2}{*}{ Morphons } & \multicolumn{4}{|c|}{ Sampling period (pairs of months) } \\
\hline & III-IV & V-VI & VII-VIII & IX-X \\
\hline \multicolumn{5}{|c|}{ Diptera (continued) } \\
\hline Helomyzidae II adult & 7 & & & 2 \\
\hline Lauxaniidae II adult & & 16 & 1 & 9 \\
\hline Limnoiidae II adult & 4 & 4 & 4 & 1 \\
\hline Limonidae I adult & & & 2 & \\
\hline Limonidae II adult & & & & 1 \\
\hline Lonchopteridae II adult & 7 & 5 & 8 & 5 \\
\hline Megamerinidae II adult & & & 5 & \\
\hline Milichiidae II adult & 8 & & 1 & 5 \\
\hline Muscidae I adult & & 6 & & \\
\hline Muscidae I pupa & & 2 & & \\
\hline Musicidae I adult & & & 2 & \\
\hline Musicidae II adult & & 1 & 14 & 5 \\
\hline Mycetophilidae I adult & 9 & & & \\
\hline Odiniidae I adult & & 5 & & \\
\hline Opomyzidae I adult & & & 4 & 1 \\
\hline Otididae II adult & & 1 & & \\
\hline Pallopteridae I adult & & & 2 & \\
\hline Periscelidae I adult & & & 3 & \\
\hline Phoridae I adult & & & 2 & \\
\hline Pipunculidae I adult & & & 3 & \\
\hline Pipunculidae II adult & & 1 & & \\
\hline Pipunculidae II adult & & 1 & 1 & \\
\hline Platypezidae I adult & & 2 & 5 & 2 \\
\hline Ptychopteridae II adult & & 4 & 5 & \\
\hline Rhagionidae II adult & & 5 & & 1 \\
\hline Rhagodidae I larva & & & 5 & \\
\hline Rhagodidae II larva & & 1 & 2 & \\
\hline Rhagodidae III larva & & & 1 & \\
\hline Scatopsidae I adult & & & & 2 \\
\hline Sciaridae I adult & 2 & 3 & 1 & \\
\hline Sciaridae II adult & & 1 & & \\
\hline Sciaridae II adult & & 1 & 2 & \\
\hline Sciomyzidae I adult & & 2 & 4 & \\
\hline Sciomyzidae II adult & & & 7 & \\
\hline Sciomyzidae II adult & & & 1 & \\
\hline Sepsidae I adult & & & 6 & \\
\hline Sepsidae II adult & 3 & & & 7 \\
\hline Sepsidae II adult & & & 1 & \\
\hline Simulidae I larva & & & 3 & 4 \\
\hline Simulidae II larva & 14 & & 10 & 1 \\
\hline Simulidae II pupa & 1 & & & \\
\hline Sphaeroceridae I adult & & & & 2 \\
\hline Sphaeroceridae I pupa & 4 & 3 & & \\
\hline Sphaeroceridae I adult & & & 3 & 2 \\
\hline Stratiomydae II adult & & 2 & 2 & \\
\hline Stratiomydae I larva & 2 & 2 & 5 & 4 \\
\hline Stratiomydae II larva & 2 & 3 & & 2 \\
\hline Stratiomydae III larva & & & 1 & \\
\hline Syrphidae II adult & 6 & 3 & 6 & 2 \\
\hline Syrphidae III adult & & 3 & & 2 \\
\hline Syrphidae III adult & & & & 1 \\
\hline Syrphidae I larva & & 2 & & \\
\hline Tabanidae I larva & & 1 & & \\
\hline Tabanidae II larva & & & 1 & \\
\hline
\end{tabular}




\begin{tabular}{|c|c|c|c|c|}
\hline \multirow{2}{*}{ Morphons } & \multicolumn{4}{|c|}{ Sampling period (pairs of months) } \\
\hline & III-IV & V-VI & VII-VIII & IX-X \\
\hline \multicolumn{5}{|c|}{ Diptera (continued) } \\
\hline Tabanidae III larva & 1 & 1 & 1 & 3 \\
\hline Tachinidae II adult & 4 & 2 & 4 & \\
\hline Thaumaleidae I adult & 1 & & & \\
\hline Tipulidae III adult & 1 & 4 & 3 & 2 \\
\hline Ulidiidae I adult & & & 2 & \\
\hline \multicolumn{5}{|c|}{ VERTEBRATA } \\
\hline \multicolumn{5}{|c|}{ Amphibia } \\
\hline Anura & & & & \\
\hline Rana arvalis I egg & & 538 & & \\
\hline Rana arvalis I tadpole & & 104 & & \\
\hline Rana arvalis III tadpole & & & 21 & \\
\hline Frogs (by count) & 64 & 53 & 76 & 25 \\
\hline
\end{tabular}

For the purpose of area-closing sampling we used two pieces of $5 \mathrm{~m}$ long curtain webs, which had on its lower part a canvas-covered iron chain and, on its top, a stretching rope. By the application of the two curtain webs and some tapered stakes, an optional part of the stream (in the range of 2-10 m long sections) can be closed unpassably for Heteroptera. The curtain web does not hampers the water current and from the separated section Heteroptera can be collected with hand-web. Length, width and areal distribution of parts with different depth can be recorded from the separated section. Furthermore, it is very important to record the vegetation coverage of the closed area.

The data gained can be applied for stream length, area, water volume and these data can be even applied for derivative data weighted by vegetation parameters. These data can be standardized by using these parameters. In this work we used our data scaled to $10 \mathrm{~m}$ stream-length, without any width, depth or vegetation correction. This sampling method has - apart from its numerous advantages - some disadvantages as well, and the majority of these disadvantages originates from the fact, that the gained sample can not be divided into subsamples, and even the separation of more, lesser sections is not advisable because of the rapidly growing fringe effect. In order to eliminate these disadvantages, we conducted roving hand-webbing collection on the full length of the section. One objective of this is to test the representativeness of the closed section sample for the full length of the observed area (verification of spatial inhomogeneities belonging to a given scale-level). The other objective is to gain an other, a faunistically more complete species list which contains even the rarer species in greater proportion. When during the roving examination some doubts emerged concerning the representativity of the sample, we repeated the area-closing on an other section and compared the two quantitative samples. Such a case happened only twice during the 10year long examination period and besides, these proved to be undue. (In the case of a more inhomogeneous coastal section, the desired extent of representativity could be achieved only by averaging more, layered samples).

In our present study, we have not exploited the quantitative characteristic of the samples (absolute individual density estimation), we only used data to compare identical areas at different dates (semi-quantitative feature). To enhance the reliability of the data we applied logarithmic transformation (to outline different levels of magnitude), thus our data are comparable with the results of other authors' surveys conducted even by different methods. 


\section{Methods of simulation modelling}

The presently used simulation modelling methods applied for seasonal dynamics of population collectives have been developed during our earlier works together with our students and colleagues $[60,61,96,97,98,99]$. This methodological approach serves the purpose to make monitoring and simulation methods easily comparable to each other. To reach this goal, we applied temporally discrete (daily recorded) deterministic biomassgrowth simulation equations and fenological connecting-functions based on them. The most detailed summary and general description of the model system can be found in our paper: [98]. The biomass module of the general model system consists of a temperaturedependent inner reproduction rate and other factors simulating interpopulational interactions and predational factors. The latter factors summarise effects of the in- and outrunning edges of the interaction graph in such a manner, that the density-dependency, all the two ways of consuming interactions (who consumes and who is consumed), static and dynamic preference, real and apparent competition can also be regarded.

In our present study we used a strongly simplified version of the above-mentioned model system which has been applied for the examined situation. In this, the interactions of the populations only emerge involved in the temperature-dependency. Simulation calculations could be done easily in MS Excel tables, the starting values of parameters has been defined based upon our field experiences and publications listed in the literature overview section. The paper from Bacchi et al [8] made us to realize the opportunity of radical simplification of the models. This paper contains faunistical data about aquatic and semiaquatic Heteroptera in Italian habitats, and the appearance data are also illustrated on $\mathrm{pH}$ and temperature charts. These graphs show that the effect curve of temperature does not come up with only one optimum, - as we supposed in our former paper [98], but it can - supposedly because of population interactions - also be multi-peaked. Correction of the starting values defined by estimation (thus the fitting of the model to field data) has been done with minimizing the sum of squares (method of least squares) with the help of MS Excel Solver program.

\section{Methods of coenological pattern-evaluation}

Examination of coenological and ecological data is a quite complicated multivariate problem, which can be handled only with the tools of biomathemathics and informatics. In case of considering more than three coenological variables (taxon or morphon) we need multivariate data-structure explorative methods to evaluate coenological patterns. The most important methods of a multivariate data analysis are the divisional (classification) and dimension-reducing (ordination) processes. About the traditional methods of multivariate biological data evaluation, works of Podani [143, 144, 145, 146] give detailed overview and outstanding methodological help. Concerning classification, work of Blashfield \& Aldenderfer [26] gives a good starting point.

Methodological development results (related to state-planes) used in this work can be found in our former publications. The basic idea for these appeared first in our papers $[72,73]$, which are dealing with water qualification based on behaviour and features of Heteroptera and habitat characterization, however, at that time the introduction of indicator coordinates took place by fuzzy clustering and not by ordination. The indirect ordination methodology used in this paper has been developed continuously in publications [48, 49, 50, 70, 79, 80] and was applied in its current form in the paper [98]. Some development of the method group were described in publications [155, 156].

The third pillar of the present work includes our biomathematical developments which are connected to simulation models [43, 60, 61, 96, 97, 98, 99]. 
The more and more exact description of states and conditions and the exploration of connections can be successfully carried out, the greater, the detailed, the more exact databases can be created. However, the greater the database is (also from the aspect of variables and objects) the more difficult is to overview the phenomena it represents. A key element therefore is the decent application and use of dimension-reducing methods. Classification methods are suitable to control the results of ordinations and they are also of a great help in further navigation in the gained, reduced dimension patterns.

The application of generally known and used ordination methods is often significantly hampered in case of huge quantity of data, especially if our objective is the simultaneous use of monitoring and simulation data.

Emerging problems can be summarized as follows:

1. Limited capacity of dimension-reducing methods. By the growth of data matrices, the running time also grows excessively, and also by the application of softwares and computers regarded as currently the best, the capacity greatly lags behind the quantity of data which would be ideally used.

2. The running problems of the majority of well-applicable programs, which is of no trouble by independent evaluations, but they make harder the evaluation of greater databases in parts.

3. The problem of newer objects. At the beginning of data evaluation, we do not possess all pieces of information which are necessary later, because the point of monitoring is that it provides a continuous observation system. On the other part, if we need to reapply all the former data by every new casual evaluation, it creates many redundancies, which in addition endangers even the stability of formerly defined considering points. The reason for this is that ordination methods always look for the actual similarity patterns of the examined objects, and all new objects can exert its effect on this process.

4. Tightly correlates with the above-mentioned facts the problem of the reliability of data, because data which are considered by us as highly or less reliable, influence the result of ordination in the same extent. Thus, incorrect data not only causes problem in the position of the given object which contains it, but can also influence the whole pattern, which obviously can not be tolerated.

5. Another problem is the deformity of the sampling net itself, because if there are certain object types that are overrepresented compared to others, then the significance of value combinations contained in more prevalent type of objects becomes overestimated and this can severely endanger the consequent interpretation of the results.

6. Sometimes the examination of new (or derived) variables, is necessary, which do not influence the pattern itself, but they behaviour inside the pattern can be informative.

7. And finally, if we even disregard the above-mentioned facts, there would be the problem that the huge quantity of objects (even in the reduced dimension space or plane) will result in an extremely dense cloud of points, so the possibility of alternative display must be provided even inside the same pattern.

To eliminate all these problems we developed the methodology of stable state-planes which are based on indirect ordination $[48,49,50,72,79,80]$.

The primary objective of our work has been to develop a unified data-handling and state-evaluation methodology for the temporal-spatial modelling and temporal-spatial simulation modelling of the ecosystems. The state-plane systems developed by us can be of great help to the examination of the following types of problems: 
- comparison of ecosystem-models which simulate in time and space with real data, the optimal setting of the fitting parameters of the models, and testing of models;

- informatic handling and evaluation of data of ecologic monitoring;

- direct application of modelling results in the monitoring;

- unified handling of field trial data and facilitation of statistical analyses;

- simulation of effects of experiments;

- examination of possible effects of climatic change;

- support of the methodology of ecological risk assessment.

The essence of indirect ordination method can be summarized as follows:

The direct dimension-reducing step made by traditional multivariate pattern analysis (data structure explorative) method algorithms (later referred as direct ordination) is not carried out on the objects, but - due to the principle of attribute-duality - on the variables. Thus, it can be considered as a kind of direct ordination, which explores the similarity pattern of the original variables (as objects) based on a part of original objects (as variables) - analysis of a transposed matrix.

Ordination of the real objects is carried out indirectly, in a separate step, using the coordinates of the variables. The simplest way of this could be if we choose for the coordinates of the object in the indirect ordination some kind of function (average, weighted average, sum etc.). Thus, the objects in this step are going to be displayed on the graph independently of their relative positions, this way solving some part of the problems mentioned among the objectives.

Direct ordination carried out to define the coordinates of variables does not apply to the whole series of data, but only to a selected, strongly filtered "reference database", which we have the opportunity to overview and know perfectly. Only this reference database has to represent the real relations between variables, later incoming data will not be able to influence this. Thus, the reliability problem becomes solved as well.

In case we calculated the coordinates of the objects, the indirect ordination is theoretically determined, but for its comprehensibility and multifunctional use, the functions of alternative display and graphics must also be provided. These functions are provided by GIS which combines the methods of database-handling and graphic display - solving the task mentioned in the last point of the objectives.

Steps of building state-plane systems can be seen in Fig. 1 .

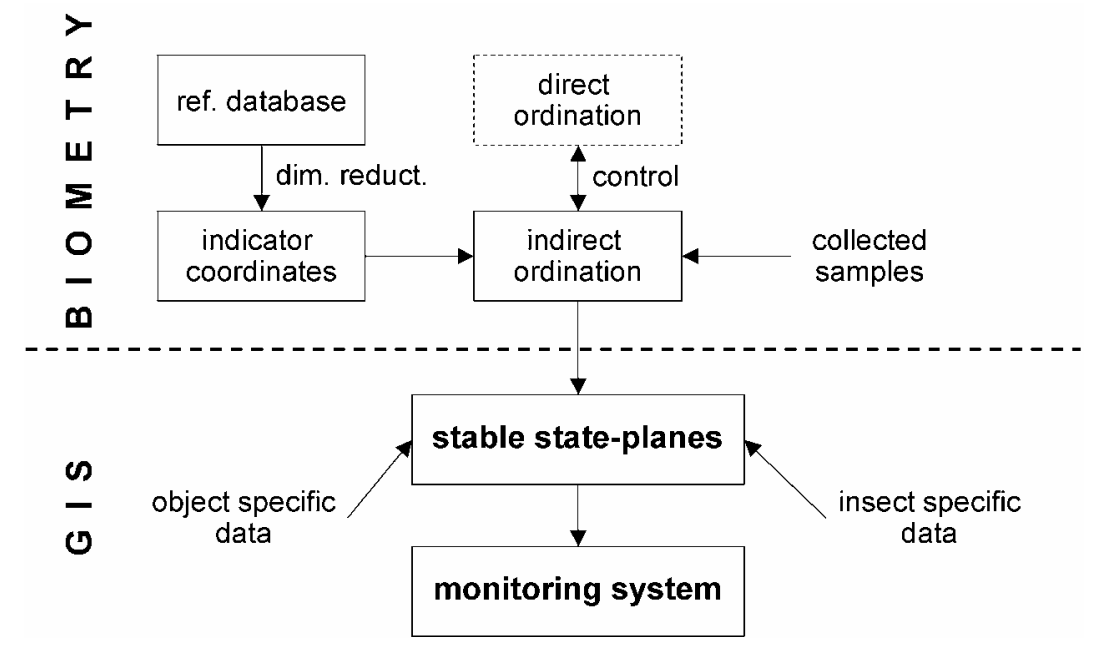

Figure 1. The process of building state-planes 
On the chart, going from the left to the right and from the top to the bottom can we proceed from the start to the use of the system. First step is the construction of the reference database. All the variables must be involved into the database which are regarded as state indicators in respect of comparison of the objects. It is very important that these indicators would be interpretable in connection with each possible objects and could take only one value in each case. Variables must be measurable independently of each other, so they can not be values computed from each other. However, from the aspect of the goodness of dimension-reduction it is of great advantage, that these variables should be in the closest statistical relationship with each other, because this way they represent information about essential characteristic (state) of the observed system. Variables omitted from the reference database and their derivatives become examinable later and with different methods with the help of the state-plane.

Next step is the direct dimension reduction based on the reference database. Its aim is to determine the coordinates of the indicator variables. When it is accomplished, a functional connection must be defined with the help of indicator coordinates between the actual values of the variables used to characterize the objects and the object coordinates of indirect ordination. If the indirect ordination is at hand, there is a possibility to check, how much the original similarity pattern of the objects would be damaged during the display with indirect ordination (for this purpose, the Shepard-diagram which is usable by nonmetric multidimensional scaling [NMDS] can also be used). It could also be very helpful to judge the goodness of indirect ordination if the direct ordination of a part of the examined objects is carried out and this can be compared with the similarity pattern achieved from the indirect ordination mentioned above. Following these testings, the behaviour of additional objects and variables (or even derived indicators) can be examind with the help of the stable (because it is interpreted between fixed points) state-plane. By the alternative display of different objects and variables on the state-plane the state-plane can be mapped, based on different aspects of examination. Among others, GIS is also suitable for handling these alternative "thematic state-maps". The state-plane system is suitable for the purpose of monitoring and evaluating infinite objects until the state of the objects remains between the states given by the reference database. Would appear there a basicly new phenomenon, it is quite uncertain that its significance would be displayed decently on the state plane. This fact calls the attention again to the significance of constructing the proper reference database. This problem can be solved - in case it is needed - with the construction of many different state-planes - according to the objective of the examination - and handling (even like meta-analyses) these alternative state-planes in one unified system.

Multivariate, stable state-plane systems based on indirect ordination are suitable for the solution of the problems defined in the objectives. These state-plane systems are however not only suitable for the mechanical display of data-series resulting from monitoring and simulation or to achieve objective comparability, but they can also fundamentally integrate these two methodologies, which came across different paths during the history of science. In case of successful fitting of these simulation models on real monitoring data-series, then it should open a broader than before horizon of interpretability of results and conclusions. In this case, there is a possibility to construct reference databases partly from empirical and partly from simulated data, which means that state-planes can be ready to handle extraordinary situations never experienced before, and this could render the usefulness and applicability of state-plane systems quite general. 


\section{Terminology, definition of concepts used}

Systems of professional terms used in supraindividual biology (meaning of concepts and the relations between them) are strongly tied to the different schools and theoretical trends. Thus, the very same professional term could bear totally distant meaning in different works. Since concepts and terms are used in many ways by different authors, it seemed to be inevitable to clearly define the terminology applied in this work.

However the objective of the definitions listed here should not be considered as a general formulation. Our task can not be therefore the modification or restriction of the well-known meanings of individual concepts. Nor could it be the definition of them by scientific claims (because many had done this before our work in many ways), only to make the terminology of this current work clear (in order to facilitate the independent comprehensibility of different parts of the text), so we regard it valid only in this respect.

- Coenology: A discipline belonging to supraindividual (syn-) biology, which deals with the description of coexistent states of living beings' (in this case animal) communities. (Pragmatic streams of this discipline are often referred to as community ecology).

- Community structural (or coenological) state: The coenological state of an examined object (habitat, sampling place, sampling unit etc.) can be explained if the presence (mass indicator, measurable with a preliminarily set observation method) or absence of the living objects involved in the study (actually defined as variables) are given. Thus, the assignment of coenological state means the disclosement of a species list and/or a quantified species list (perhaps density distribution) by very strict rules.

- (Coenological) change of state: By the terminology of this current work, every temporal-spatial processes, in which any of the variables of the above-mentioned coenological state alters, is regarded as a (coenological) change of state, regardless to its reason or statistical feature.

- Coenological behaviour: Temporal or spatial pattern of change of state, which can apply for the whole or for any part of the community.

- Coenological monitoring or monitoring: Series of field observations done in many steps with defined objective and adequate method, which traces temporal changes of state on a fixed scale and period of time.

- Monitoring system: Monitoring is only feasible in the frame of a monitoring system. A monitoring system can be considered defined, when the following necessary conditions are set: objects (or the group of objects), variables (in this case: living beings), period of examination, frequency (or other succession) of the observed (sampling) units, methods of data collection, method of filling of the database and methods of primary data processing. In this current work, only series of examinations conducted in the same year can be considered as monitoring.

- Simulation: Generation of artificial data series with the help of a mathematical model. Data structure resembles to temporal coenological change of state.

- Simulation model: Very precise formulation of hypotheses and conditions applying to a temporal change of state with mathematical methods. (When the system of hypotheses and conditions are put in text, it can be accomplished by many (even significantly different) simulation models, because model is a more accurate, therefore a more restricted phrase.)

- Scenario: Result of the simulation, which is an (realistic, but not definitely real) outcome of the given model and parameters of the observed state of change. 
Scenario is not a forecast, it is only one of the alternative possibilities. Usually probability of outcome can not be attributed to scenarios (or only in form of "professional estimate").

- (Coenological) indication: A signal, in this case the information content of coenological state or change of state, which applies to the state or change in state of other conditions or variable groups. In this work, it occurs exclusively in relation to seasonal dynamics (actual position in an intra-annual trajectory of change of state). In this case, similarity pattern shown by sampling units based on a group of variables (indicator organisms) indicates the similarity pattern of the identical sampling units based on other variables. (Indication does not denote cause and effect connection).

- Indicator organism: In the terminology of this current work, it is an optional kind of living organisation which we involve in the group of variables, such playing a role in the coenological indication. (Thus, in itself it does not indicate anything, it is only one of the units of the indicators of the coenological state, which gives us an indication.)

- Morphon: Some kind of living organism, which can be unanimously identified and distinguished based on morphological characteristics. In this current work, it is a unit which contains taxon (taxonomical name), life-cycle state and/or body size category. The applied indicator organisms were identified as morphones. The reason, why the concept of morphon had to be introduced was that different development stages of a taxon often showed more different behaviour than similar development stages from other taxa.

- Autochtone species: Its full life-cycle takes place on the examined habitat.

- Allochtone species: Spends only a part of its life-cycle on the examined habitat.

- Coenological state-plane, stable state-plane: Plane - created by indirect application of multivariate dimension-reducing methods (on a reference database) - on which all the states can be definitely signed with only one point and every change of state with two points or a vector (map of the possible states). The attribute "stable" refers to its special characteristic: newly, later drawn points do not influence each other's position unlike by direct ordination methods.

\section{Results}

\section{Overview of the examined aquatic and semiaquatic Heteroptera community from the aspect of field data}

Comparison with the fauna of other aquatic biotopes, and the analysis of the similarity patterns of the aquatic and semiaquatic Heteroptera fauna of the Szilas stream are in the following papers: [37, 74, 183].

During the examination of the Heteroptera species community of the Szilas stream, all collected Heteroptera individuals from water or water-plants has been identified, disregarding how they entered this biotop. Thus 57 species from 16 families came into the sight of the examination. So not only those aquatic and semiaquatic Heteroptera species (Gerro- and Nepomorpha) which stand in the closer direction of the examination were studied, but even those Heteroptera, which life-conducts are in different extent tied to water or even species living on the land (but drifted into water by chance). Most of the publications about aquatic biotops do not contain these data, so in this respect there were not possible to compare these facts with them. Table 2 . shows the collected species and in what extent they are tied to water. 
Table 2. Heteroptera species collected on Szilas stream between 1991-2002 and categories of their life-conduct from the aspect of water-tiedness. Aquatic: *****; semiaquatic: ****; coastal: ***, living close to water because of their characteristic feed-plant (or from other indirect reason): **, frequent in the proximity of water (as well): *

\begin{tabular}{|c|c|c|c|}
\hline $\operatorname{taxa}$ & $\begin{array}{c}\text { water- } \\
\text { tiedness }\end{array}$ & taxa & $\begin{array}{c}\text { water- } \\
\text { tiedness }\end{array}$ \\
\hline $\begin{array}{l}\text { GERROMORPHA } \\
\text { Gerridae }\end{array}$ & & $\begin{array}{r}\text { LEPTOPODOMORPHA } \\
\text { Saldidae }\end{array}$ & \\
\hline Aquarius p. paludum (Fabricius, 1794) & $* * * *$ & Chartoscirta elegantula (Fallén, 1807) & $* * *$ \\
\hline Gerris argentatus Schummel, 1832 & $* * * *$ & Chartoscirta cincta (Herrich-Schäffer, 1841) & $* * *$ \\
\hline Gerris asper (Fieber, 1860) & $* * * *$ & Saldula arenicola (Scholtz, 1847) & $* * *$ \\
\hline Gerris lacustris (Linnaeus, 1758) & $* * * *$ & Saldula pallipes (Fabricius, 1794) & $* * *$ \\
\hline Gerris odontogaster (Zetterstedt, 1828) & $* * * *$ & Saldula pilosella (Thomson, 1871) & $* * *$ \\
\hline Gerris odontogaster larva & $* * * *$ & Saldula saltatoria (Linnaeus, 1758) & $* * *$ \\
\hline Gerris thoracicus Schummel, 1832 & $* * * *$ & Saldula opacula (Zetterstedt, 1838) & $* * *$ \\
\hline Limnoporus rufoscutellatus (Latreille, 1807) & $* * * *$ & CIMICOMORPHA & \\
\hline Hydrometridae & & Tingidae & \\
\hline Hydrometra stagnorum (Linnaeus, 1758) & $* * * *$ & Dictyla humuli (Fabricius, 1794) & $* *$ \\
\hline $\begin{array}{c}\text { Mesoveliidae } \\
\text { Mesovelia furcata Mulsant \& Rey, } 1852\end{array}$ & $* * * *$ & $\begin{array}{l}\text { Agramma confusum (Puton, 1879) } \\
\text { Tingis ampliata (Herrich-Schäffer, 1839) }\end{array}$ & \\
\hline \begin{tabular}{l}
\multicolumn{1}{c}{ Veliidae } \\
Microvelia reticulata (Burmeister, 1835) \\
Microvelia pygmea (Dufour, 1833) \\
Velia s. saulii Tamanini, 1947
\end{tabular} & $\begin{array}{l}* * * * \\
* * * * \\
* * * *\end{array}$ & $\begin{array}{l}\quad \text { Nabidae } \\
\text { Nabis ferus (Linnaeus, 1758) } \\
\text { Nabis pseudoferus Remane, } 1949 \\
\text { Nabis punctatus Costa, } 1847\end{array}$ & $*$ \\
\hline $\begin{array}{l}\text { NEPOMORPHA } \\
\text { Nepidae } \\
\text { Nepa cinerea Linnaeus, } 1758 \\
\text { Ranatra linearis (Linnaeus, 1758) }\end{array}$ & $\begin{array}{l}* * * * * \\
* * * * *\end{array}$ & $\begin{array}{l}\quad \text { Miridae } \\
\text { Stenodema calcarata (Fallén, 1807) } \\
\text { Polymerus holosericeus (Hahn, 1831) } \\
\text { Adelphocoris seticornis (Fabricius, 1775) } \\
\text { Adelphocoris lineolatus (Goeze, 1778) }\end{array}$ & $*$ \\
\hline Notonectidae & & Orthops sp. & \\
\hline $\begin{array}{l}\text { Notonecta g. glauca Linnaeus, } 1758 \\
\text { Notonecta viridis Delcourt, } 1909\end{array}$ & $\begin{array}{l}* * * * * \\
* * * * *\end{array}$ & $\begin{array}{c}\text { Anthocoridae } \\
\text { Dysepicritus rufescens (Costa, 1843) }\end{array}$ & $* *$ \\
\hline $\begin{array}{c}\text { Pleidae } \\
\text { Plea m. minutissima Leach, } 1817\end{array}$ & $* * * * *$ & $\begin{array}{l}\text { Orius laticollis (Reuter, 1884) } \\
\text { Orius (Heterorius) sp. }\end{array}$ & \\
\hline $\begin{array}{r}\text { Corixidae } \\
\text { Corixa affinis Leach, } 1817\end{array}$ & $* * * * *$ & $\begin{array}{l}\text { PENTATOMOMORPHA } \\
\text { Scutelleridae }\end{array}$ & \\
\hline Corixa panzeri Fieber, 1848 & $* * * * *$ & Eurygaster testudinaria (Geoffroy, 1785) & \\
\hline Corixa punctata (Illiger, 1807) & $* * * * *$ & Eurygaster maura (Linnaeus, 1758) & \\
\hline Hesperocorixa linnaei (Fieber, 1848) & $* * * * *$ & & \\
\hline Paracorixa c. concinna (Fieber, 1848) & $* * * * *$ & Dolicoris baccarum (Linnaeus, 1758) & \\
\hline $\begin{array}{l}\text { Sigara falleni (Fieber, 1848) } \\
\text { Sigara lateralis (Leach. 1817) }\end{array}$ & $\begin{array}{l}* * * * * \\
* * * * *\end{array}$ & Aelia acuminata (Linnaeus, 1758) & \\
\hline Sigara $n$. nigrolineata (Fieber, 1848) & $* * * * *$ & Lygaeidae & \\
\hline Sigara striata (Linnaeus, 1758) & $* * * * *$ & Cymus melanocephalus Fieber, 1861 & $*$ \\
\hline Cymatia rogenhoferi (Fieber, 1864) & $* * * * *$ & Cymus glandicolor (Hahn, 1831) & $*$ \\
\hline Micronecta scholtzi (Fieber, 1860) & $* * * * *$ & Raglius confusus (Reuter, 1886) & \\
\hline
\end{tabular}

Summarized collection data of three observation years with the greatest temporal frequencies provides a possibility to examine the quantitative relations of the aquatic and semiaquatic Heteroptera communities (Table 3). Based on the data of Table 3 it can be stated, that out of the 22 collected species only 6 are represented with greater than $1 \%$ dominance (Gerris lacustris, G. thoracicus, G. odontogaster, Hydrometra stagnorum, 
Table 3. Relative occurrence by number of individuals of aquatic and semiaquatic Heteroptera (dominance\%) on the examined section of Szilas stream

\begin{tabular}{|c|c|c|c|}
\hline Taxa & Szilas 1994 & Szilas 1996 & Szilas 2002 \\
\hline \multicolumn{4}{|l|}{ GERROMORPHA } \\
\hline Aquarius paludum paludum (Fabricius, 1794) & & 0.23 & 0.2 \\
\hline Gerris argentatus Schummel, 1832 & & 0.05 & 0.13 \\
\hline Gerris asper (Fieber, 1860) & & 0.99 & 0.04 \\
\hline Gerris asper larva & \multicolumn{3}{|c|}{0.49} \\
\hline Gerris lacustris (Linnaeus, 1758) & 11.66 & 18.83 & 32.41 \\
\hline Gerris lacustris larva & 10.76 & 24.64 & 55.65 \\
\hline Gerris odontogaster (Zetterstedt, 1828) & \multirow{6}{*}{0.27} & 1.71 & 0.13 \\
\hline Gerris odontogaster larva & & 0.28 & 0.04 \\
\hline Gerris thoracicus Schummel, 1832 & & 6.74 & \multirow[t]{4}{*}{0.47} \\
\hline Gerris thoracicus larva & & 1.28 & \\
\hline Limnoporus rufoscutellatus (Latreille, 1807) & & 0.1 & \\
\hline Limnoporus rufoscutellatus larva & & 0.01 & \\
\hline \multicolumn{4}{|l|}{ Hydrometridae } \\
\hline Hydrometra stagnorum (Linnaeus, 1758) & 7.17 & 2.26 & 1.37 \\
\hline Hydrometra stagnorum larva & 0.63 & 0.53 & 0.4 \\
\hline \multicolumn{4}{|l|}{ Veliidae } \\
\hline Microvelia reticulata (Burmeister, 1835) & & 0.03 & 0.09 \\
\hline Microvelia reticulata larva & & 0.04 & \\
\hline Velia saulii Tamanini, 1947 larva & & 0.01 & \\
\hline \multirow{2}{*}{\multicolumn{4}{|c|}{ NEPOMORPHA }} \\
\hline & & & \\
\hline Nepa cinerea Linnaeus, 1758 & 13.36 & 1.99 & 0.59 \\
\hline Nepa cinerea larva & 34.26 & 4.12 & 3.86 \\
\hline Ranatra linearis (Linnaeus,1758) & & 0.05 & \\
\hline \multicolumn{4}{|l|}{ Notonectidae } \\
\hline Notonecta glauca glauca Linnaeus, 1758 & 21.61 & 32.24 & 2.99 \\
\hline Notonecta glauca larva & 0.09 & 0.32 & 0.61 \\
\hline Notonecta viridis Delcourt, 1909 & & 0.56 & \\
\hline \multicolumn{4}{|l|}{ Pleidae } \\
\hline Plea minutissima minutissima Leach, 1817 & & 0.55 & 0.17 \\
\hline Plea minutissima larva & & 0.1 & \\
\hline \multicolumn{4}{|l|}{ Corixidae } \\
\hline Corixa panzeri Fieber, 1848 & & 0.03 & \\
\hline Corixa punctata (Illiger, 1807) & & 0.26 & \\
\hline Hesperocorixa linnaei (Fieber, 1848) & 0.18 & 0.19 & 0.04 \\
\hline Hesperocorixa linnaei larva & & & 0.04 \\
\hline Sigara falleni (Fieber, 1848) & & 0.01 & \\
\hline Sigara lateralis (Leach, 1817) & & 0.44 & 0.07 \\
\hline Sigara lateralis larva & & 0.03 & \\
\hline Sigara nigrolineata nigrolineata (Fieber, 1848) & & 0.03 & \\
\hline Sigara striata (Linnaeus, 1758) & & 0.09 & 0.04 \\
\hline Micronecta scholtzi (Fieber, 1860) & & 0.73 & 0.07 \\
\hline Micronecta scholtzi larva & & 0.04 & 0.59 \\
\hline
\end{tabular}

Nepa cinerea and Notonecta glauca). In Table 3, the nomenclature used by Aukema \& Rieger [6] has been considered as a guide, and for the identification, works of Hufnagel \& Vásárhelyi [76], Jansson [82, 83], Macan [108], Štusák [181], Vásárhelyi [188], Vásár- 
helyi \& al. [195], Vepsäläinen \& Krajewski [196] has been also considered. These six species together represent $95-99 \%$ of the individuals collected altogether. Thus, they are in dominant majority. From this six species, only four can be considered in its larva and adult form to be constant. Individual number of the collected larvae of Gerris lacustris and Nepa cinerea exceed the number of adults, thus these can be considered as autochtonic species. In the case of Notonecta glauca and Hydrometra stagnorum only a negligible number of larvae has been collected compared to the number of adults, so one part of the population is of autochtonic, the other is of allochtonic (migrant) origin. Individuals with ability to fly and with full wings are in minority among the collected individuals of Gerris lacustris (wing polymorphism), Notonects fly well, Nepas and Hydrometras are unable to fly. The low count of Hydrometra larvae can not be satisfyingly reasoned, although among Gerromorphans, most often hydrometrids crouch up to the plants above the water. The eight kind of living organisms (containing larvae and adults of the four constant-dominant species) were appointed as coenological indicatororganisms, their coenological indication (prediction) power is detailed in sections Seasonal dynamic patterns represented by field data and Comparison of simulation and monitoring on a coenological state-plane.

\section{Seasonal dynamic patterns represented by field data}

For the survey of empirical seasonal dynamic patterns, the data series of the years 1996 and 2002 are the most suitable, because sampling in these periods took place weekly or fortnightly. Observation data from the rest of the years (sampling monthly or more rarely) are suitable for testing hypotheses. In the series of data from 1996 (the year with the greatest sampling frequency from the aspect of Heteroptera) the proportion of the eight indicator organisms (larvae and adults of the four constant-dominant species) in the whole Heteroptera community, and the information content applying to the coenological change of state of the Heteroptera community can be well demonstrated. A great advantage of the 2002 series of observations are that they provide a possibility to compare the coenological behaviour (similarity pattern of the phases of the series of change of state) of the 8 dominant indicator organisms and the absolute dominant (non-Heteroptera) species of the aquatic macroinvertebrate community.

\section{Empirical patterns of the year 1996}

For the characterization of the seasonal change of state, firstly the formation of the summarised indicators is worth to be surveyed. All of the indicators have been counted for the whole aquatic and semiaquatic Heteroptera communities and separately to the eight indicator organisms as well. We signed the latter on the figures with a comma in the upper index. In Figs. 2-5, values of total number of collected individuals, total number of kinds of living organisms (species + their development stages), $\log _{10}$ sum of total individual numbers, and Shannon diversity can be seen. For the course of individual numbers, it can be stated that approximately until the $250^{\text {th }}$ day of the year - with fluctuations they grow nearly linear in their trend, and after this date, steeply and near linearly again they drop. It can be also observed, that the two curves of individual numbers diverge from each other in the greatest extent in the growing phase; but in the phase of decline they draw very near. This means that the non-dominant species emerge in great numbers at a time, when the dominant species are still in intensive growth. (Presumably they do not exploit at this time the available resources, so there's a weak competition pressure). The number of kinds of organisms, which is displayed in Fig. 3, strengthens this theory, 
amended with the fact that the number of kinds of organisms reach the peak around the $140^{\text {th }}$ day and after this date - with small fluctuations - they remain on peak until the previous date of the peak of individual numbers. Running of the curves of Fig. 4, which displays the sum of logarithms shows a transition between the formerly discussed two figures - this is in line with expectations because we apply logarithm in order to recognize changes in order of magnitude. In this figure, the gradual diversion in the growing phase, and the approach in the declining stage of the two curves can be observed at best, which points to the essence of the pattern in a more sophisticated way. Fig. 5, which displays the behaviour of the diversity indices, makes it clear that after reaching the peak of number of kinds, the reduction in diversity is caused by the decline of the evenness of the frequency distribution. So, after the $150^{\text {th }}$ day, the dominance of the dominant species grows firmly. And this also means that primarily the dominant species participate in ill-proportioned extent from the fast growth of individual numbers. Decline in individual numbers occurs by the conservation of these proportions, so during the year the development stages of the 4 constant-dominant species gradually crowd out the others.

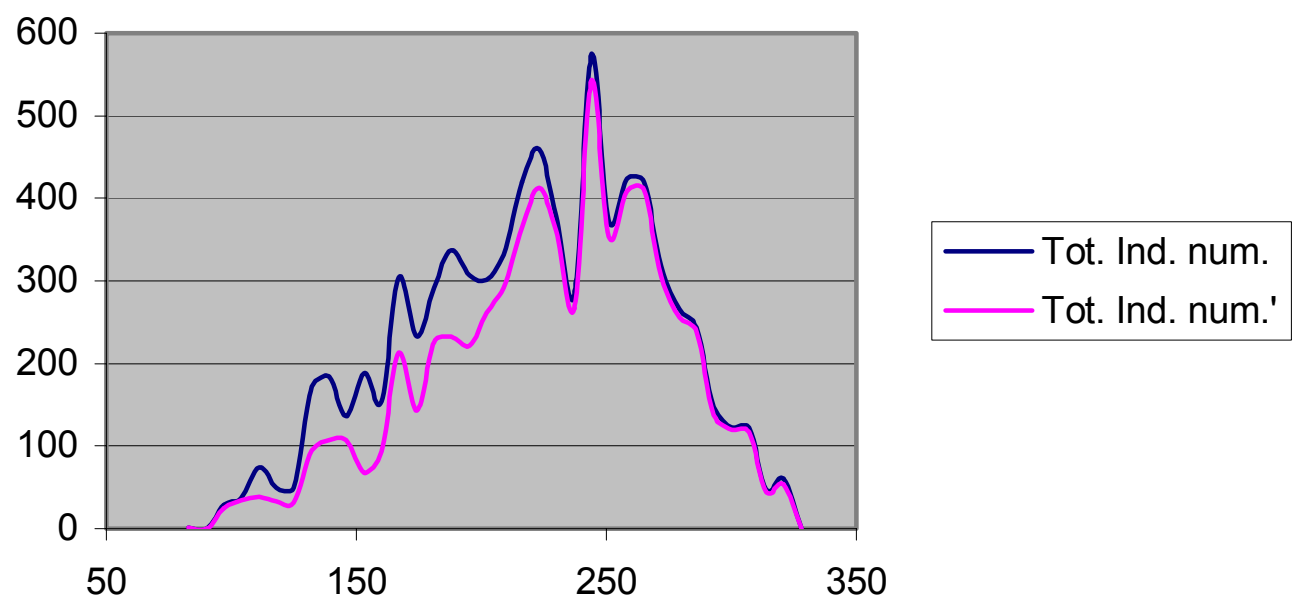

Figure 2. Total individual number of samples in 1996

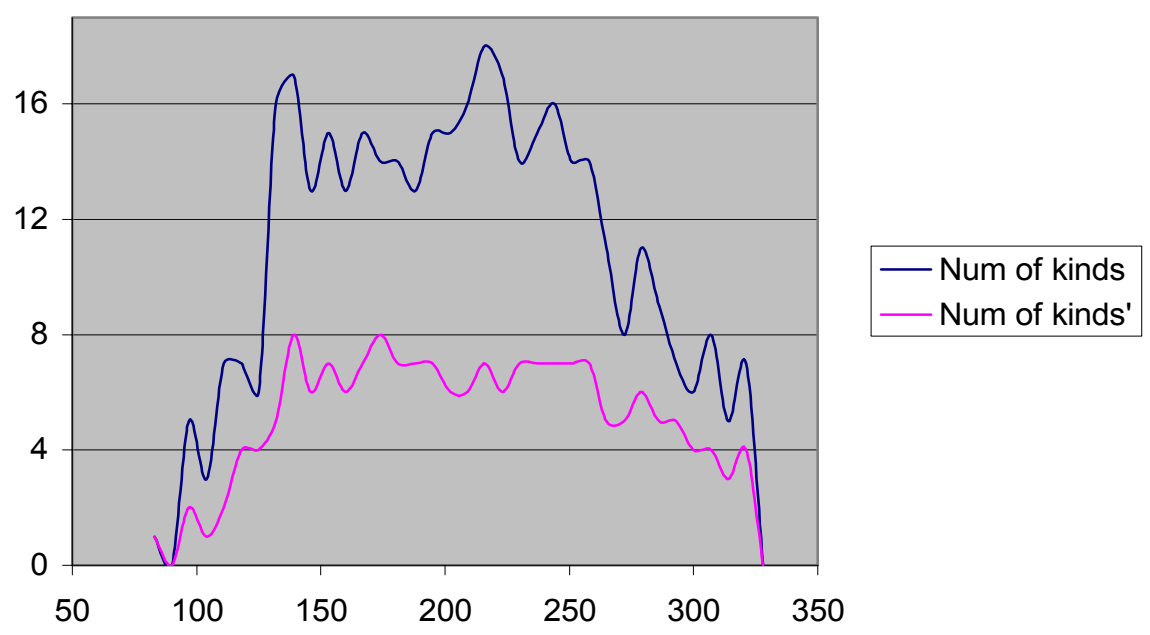

Figure 3. Number of kind of living organisms (development stages of Heteroptera species) found in samples in 1996 


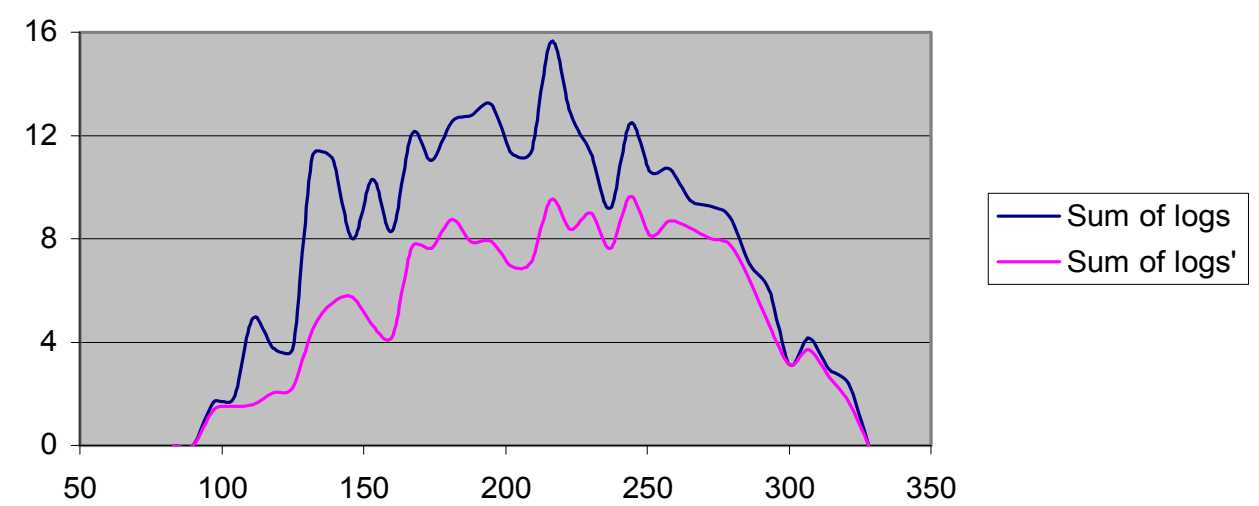

Figure 4. Sum of individual number logarithms of number of kind of living organisms found in samples in 1996

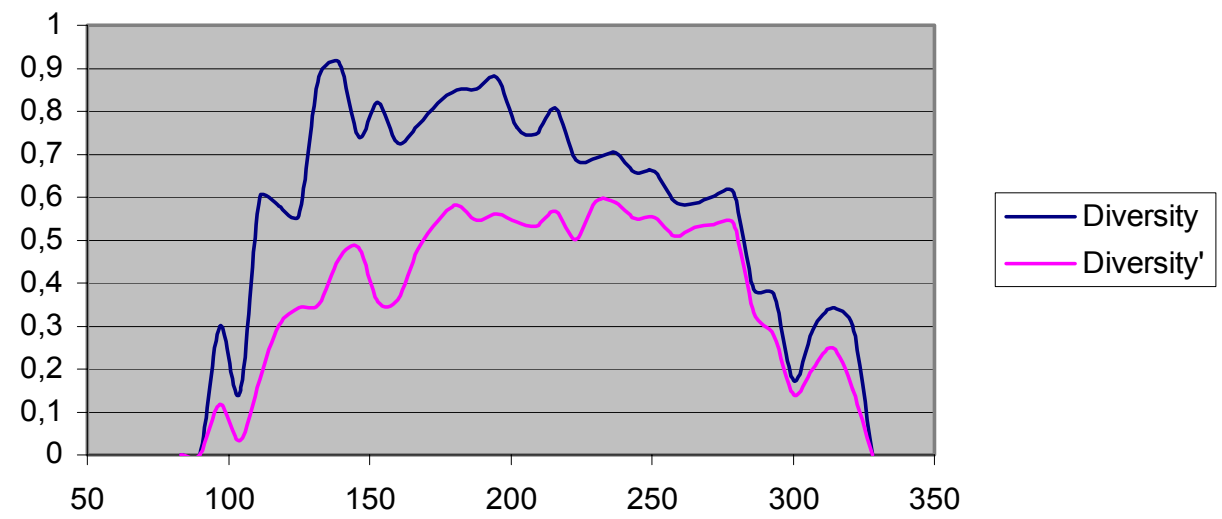

Figure 5. Values of Shannon-diversity in 1996

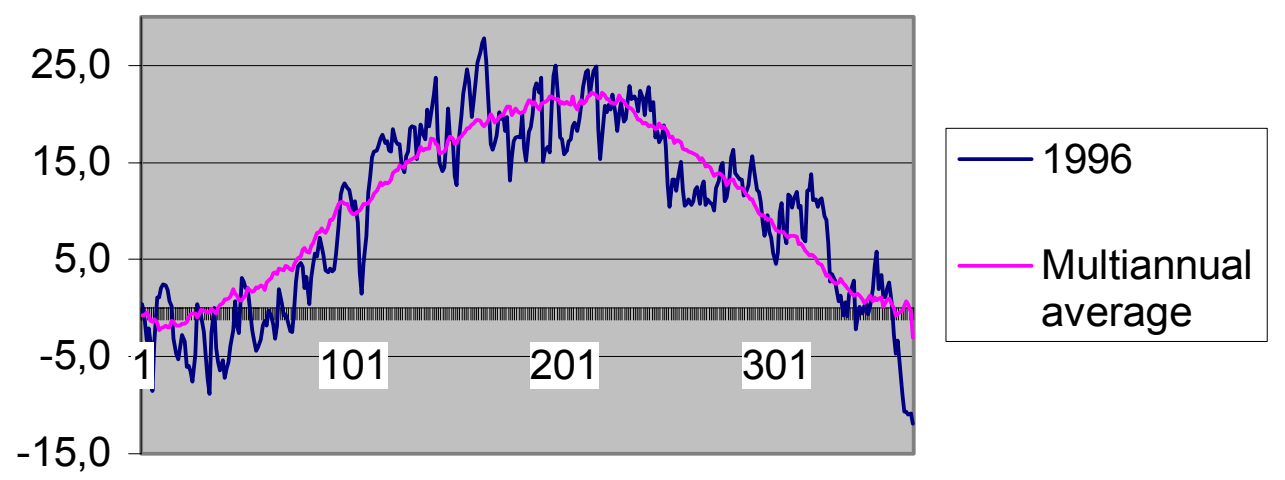

Figure 6. Daily mean temperatures in 1996 and the multiannual average of daily temperatures

In Fig. 6 the daily mean temperatures are displayed. It can not be disregarded, that the shape of this curve is quite parallel to the afore-mentioned curves. This supports the theory that temperature has a decisive role in the forming of seasonal patterns.

Conjugated indicators, which unify variables by different methods help to give a picture of the process of change of state, but the conjugations hide the similarity patterns of 


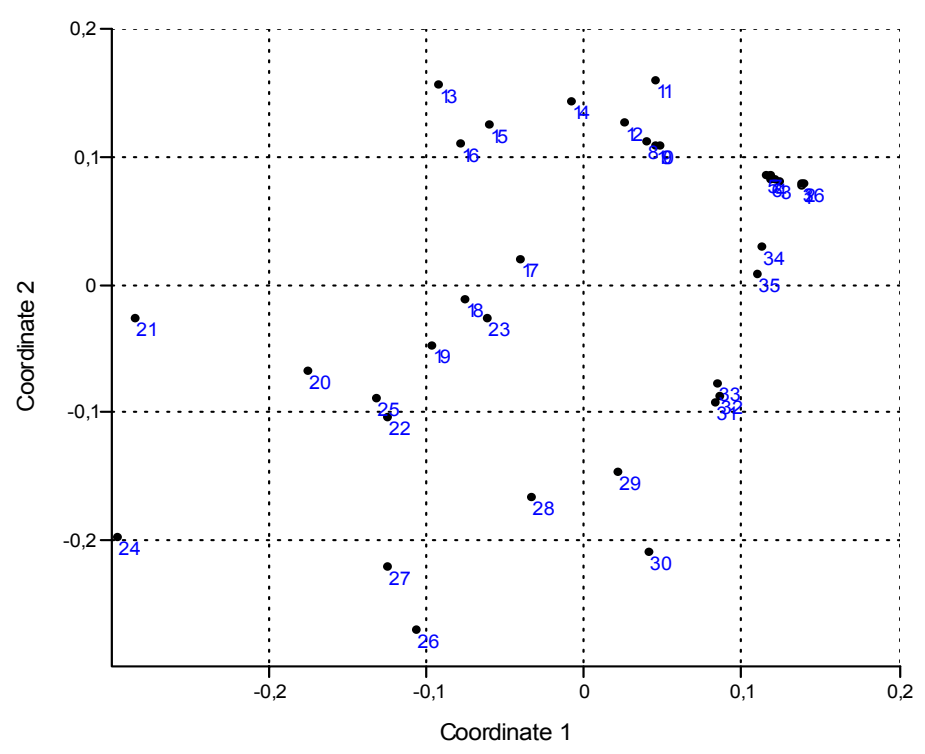

Figure 7. Coenological changes of state of the Heteroptera community in 1996. NMDS ordination with euclidean distance. Serial numbers on the chart denote sampling dates from the $12^{\text {th }}$ week of 1996, taken daily, by Saturdays.

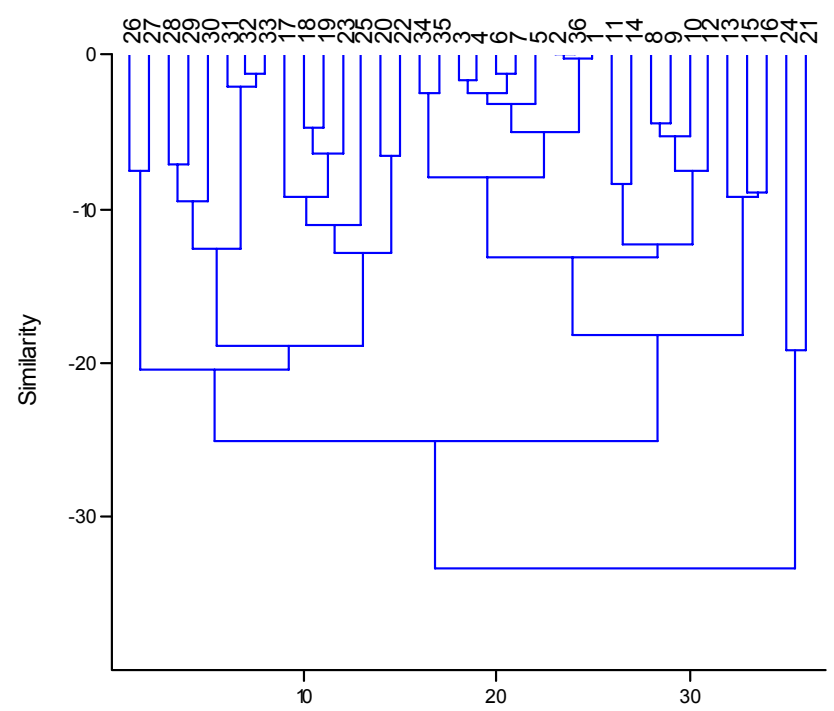

Figure 8. Classification of the samples from the 1996 year with UPGMA method (group averages). (Serial numbers are identical to the numbers in Fig. 7)

coenological states. To the analysis of temporal similarity patterns of coenological states, the application of multidimensional dimension-reducing and classifying methods lead us nearer. Pattern analyses have been carried out for the whole of the Heteroptera community and separately for the selected indicator organisms in order to test the predictive power of the patterns of indicator organisms. The similarity patterns have been explored with NMDS (Figs. 7 and 9), and for the testing of groups, cluster analyses have been carried out (Figs. 8 and 10) by applying the same distance function. Reliability of ordinations have been justified even with Shepard-diagram (Figs. 11 and 12). 


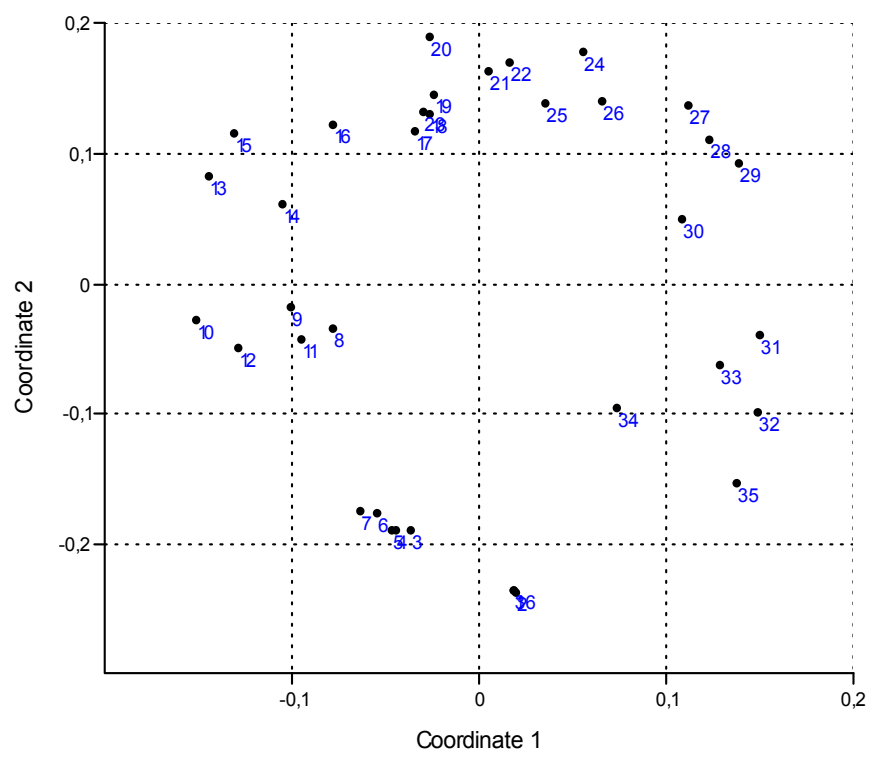

Figure 9. Coenological changes of state and similarity pattern of dates of the indicator organisms from the 1996 year. NMDS ordination, euclidean distance. (Serial numbers are identical to the numbers in Fig. 7)

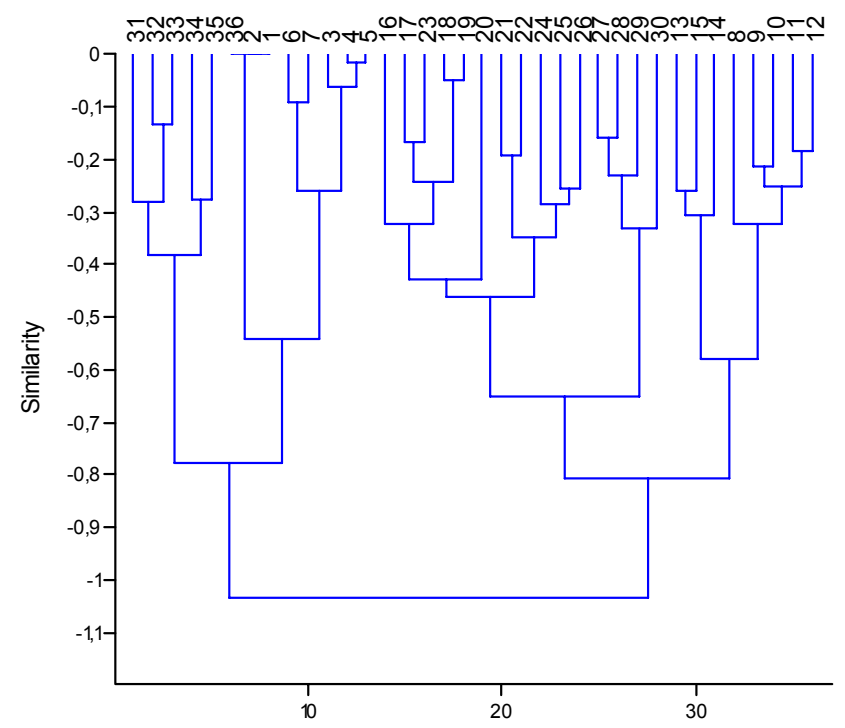

Figure 10. Classification of samples by indicator organisms from the 1996 year, with UPGMA method, euclidean distance. (Serial numbers are identical to the numbers in Fig. 7)

It can be observed in both of the ordination figures, that during the vegetation period (and practically during a year), coenological states describe a cycle of change of state which explains seasonality. Fig. 9, which displays exclusively the constant-dominant indicator organisms, shows a more regular trajectory than Fig. 7, which displays all species of Heteroptera.

The reason for this is that forms with little frequency (closer to the sampling threshold) are stronger influenced by random admission (noise of information) into 


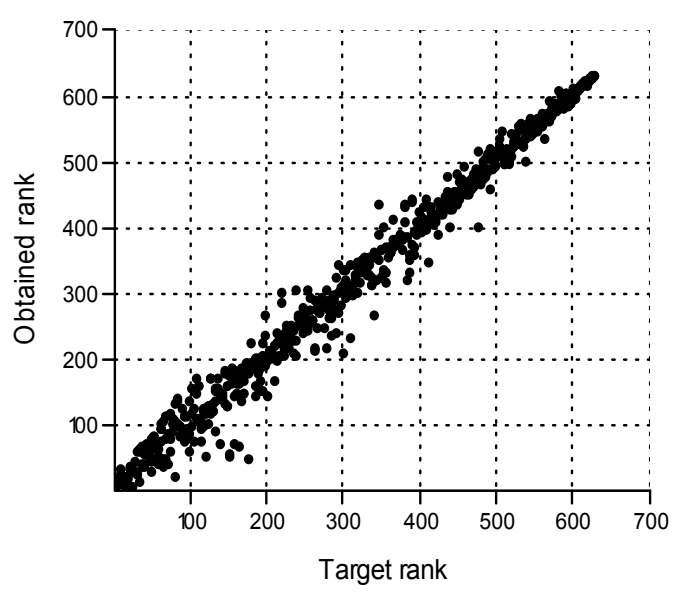

11

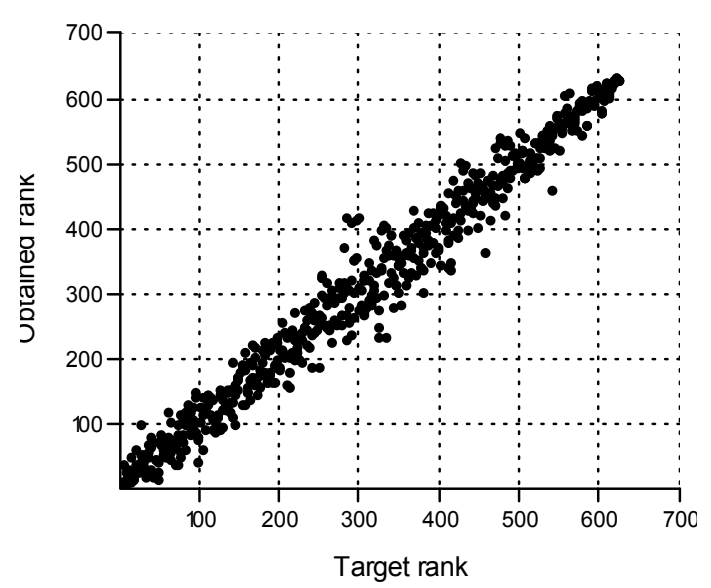

12

Figures 11, 12. Shepard-diagram to 11: Fig 7 and 12: Fig. 9.

samples. However, this can not hide the basic pattern-generating processes. Another important and well-studiable pattern characteristic is (apart from seasonal cycle), that points representing the samples are not evenly positioned along the line of the imaginary trajectory, but they form small groups. It can be well observed by comparing ordinations and classifications pairwise, that these groups are not artificial analysis products, but units of the real pattern. Using the traditional concepts of coenology [15, $16]$ these groups can also be called as aspects. Within the aspects the changes are slow, but at the time of changing of aspects, changes become fast.

\section{Hypothesis system and model for the interpretation of the patterns gained}

During the evaluation of the series of field data, temporal (seasonal scale) pattern of the coenological changes of state of the aquatic and semiaquatic Heteroptera community has been drawn. Results of the analysis indicated that temporal changes of weather parameters may have a decisive role in the determination of the patterns. Moreover, a very important result is that by selecting the larvae and adults of the four constantdominant species of the Heteroptera community, we get eight indicator organisms, which seasonal behaviour is of predictive power for the seasonal changes of state patterns of the whole macroinvertebrate community. Thus, the similarity pattern shown by the seasonal changes in the state of those Heteroptera species providing the indicator organisms resembles to the pattern shown by dominant (non-Heteroptera) organisms. Presumably the strong ecological pattern-generating role of weather stands behind this phenomenon. The descriptive analysis of the patterns can only foreshadow the causeeffect relations, but it is incapable of exploring them. The complete exploration of the complicated interaction system which exert its effect inside the community would require the work of many researches during many decades. Between the frames of this current work however, it seems to be a realistic task to summarise - obviously by a strongly simplified hypothesis-system - the presumptions to the causes of the seasonal behaviour of indicator organisms. During the formulation of the hypothesis-system, the task is to grab and to stress the most important phenomena, which can be achieved by disregarding or - in a strongly simplified manner - conjugating the greatest part of interactions, which are otherwise interesting and important. To test the interpreting 
power of the hypothesis system, a mathematical model of the hypothesis system has to be formed in such a way, that it should be directly comparable with the observations.

The objective of the model is to examine, whether the seasonal change of daily mean temperatures in itself could cause seasonal coenological change of state pattern, which resembles to the results of series of field observations.

In our previous works, we worked out general simulation model-systems for the modelling of the seasonal-dynamic processes of communities (see subsection of literature overview). The best summarising description of the model-system applied here can be found in the paper [96]. For the modelling of the Heteroptera community on Szilas stream, we wanted to formulate such a hypothesis-system, which provides the possibility to adopt our general model-system to the current situation (see methodological subsection: Methods of simulation modelling) and simultaneously defines the validity limits of the model.

According to the above-mentioned objectives, the following hypothesis- and condition-system were formulated:

1. The biomass-dynamic of the populations of different species is determined basicly by the change of daily mean temperature.

2. Strength of population interactions (direct consuming relations, source competition, apparent competitions, other direct interactions) and their resultant effect influencing a given population are also a function of daily mean temperature.

3. Feeding network of the community is decisively based on detritivor organisms, thus the main system-ecological processes are donor-controlled, but the detritus stocks are always abundant.

4. Structure of the dominant species of the observed habitat can change only in proportions but these dominant species locally do not extinguish and later arriving (migrant, invasive) species do not become dominant (or if they do, this does not influence the examined seasonal-dynamic processes).

5. Occurrence dates of phenologic (and individual development) phases are exclusively determined by an effective heat sum which is specific for the given phase (heat sum unit), and the physiologic condition of the given individual.

6. Individuals with different physiologic state in the population constitute a small number of discrete sub-populations.

7. Differences in the physiological state of the individuals in the populations determine only the starting values of the additive heat sum units (condition, stored quantity of nutrients), but there is no difference in the speed of accumulation.

8. Actual number of the indicator organisms is only determined by the local phenologic changes, and the possible immigration or emigration from the imminent proximity (migration). In respect of phenologic stages, nearly identical states are present in the neighbourhood of the examination spot.

9. Migration can only level off those differences, which are actually existing between the temperature-dependent potential and the locally and historically developed number of individuals. (Thus, the arriving immigrants beyond the subsistence level move away or die instantly, but the headcount up to the possibilities can be filled even by migration).

10. Weather phenomena occurring in winter - before the 80th and after the 340th day of the year - do not influence the processes in the vegetation period because of the diapause characteristics of the species. (Individual development stages do not take place even if the weather should be otherwise favourable). 
11. All the observed species overwinter exclusively in adult form.

12. Apart from the above-mentioned factors other (disregarded) factors do not effect the community.

The hypothesis-system above can be formulated mathematically in the following model:

$$
\begin{gathered}
X_{i, t}=\left\{\begin{array}{cc}
\log _{10} A_{i, t}, & \text { if } A_{i, t} \geq 1 \\
0 & \text { otherwise }
\end{array} ;\right. \\
i=1,2, \ldots, 8 ; \\
t=1,2, \ldots ; \\
A_{i t}=\sum_{t-5}^{t+5} \frac{B_{i t} \cdot C_{i t}}{11} ; \\
B_{l t}=R_{l T} \cdot B_{l t-1} ; \\
l=1,2,3,4 ;
\end{gathered}
$$

where

$X_{i, t}$ : order of magnitude of the predicted individual number of the $i^{\text {th }}$ kind of organisms

on the $\mathrm{t}^{\text {th }}$ day (this is desired to be gained with the simulation);

$A_{i, t}:$ number of individuals ( $i^{\text {th }}$ kind of organism on the $t^{\text {th }}$ day);

$R_{l, T}$ : a constant ordered to temperature intervals, which is a parameter of the model;

$i$ : index of the kind of organism (given development stage of a given species);

$l:$ index of the species;

$t$ : serial number of a day in a year;

$T$ : daily mean temperature;

$B_{i, t}$ : actual value of the biomass of the population;

$C_{i, t}$ : proportion of the individual development stage in question in the population of the species.

$$
\begin{gathered}
C_{i, t}=\frac{\sum_{n} D_{i t n}}{\sum_{n} D_{i t n}+\sum_{n} D_{j t n}}, \\
D_{i t n}=a_{n} \cdot E_{i}\left(F_{n t}\right),
\end{gathered}
$$

where

$n$ : index of sub-populations;

$a_{n}$ : a constant characterizing the magnitude of the $n^{\text {th }}$ sub-population,

$E_{i}$ : switch function, which can take only the values of 1 or $0 ; 1$ if it is in the range of the

$F_{n t}$ effective heat sum unit model, and 0 if it is outside the range;

$D_{i t n}$ : mass indicator of the given individual development stage of the given species $\left(i^{\text {th }}\right.$

kind of organism);

$D_{j t n}$ : mass indicator of the other development stages of the given species.

$$
F_{n t}=d_{n}+\sum_{k=t_{0}}^{t} T_{k}
$$

where 
$d_{n}$ : condition of the $n^{\text {th }}$ subpopulation (starting value of the heat sum measurement);

$t_{0}:$ starting day in the spring (here, the $80^{\text {th }}$ day of the year);

$T_{k}$ : value of the ${ }^{\circ} \mathrm{C}$ degrees above the species-specific base temperature on the $k^{\text {th }}$ day.

With the model above, the change in the individual number of species and their development stages can be easily calculated if we write the equations into one row of the MS Excel (into cells referring to each other) and copy them below each other so many times, as many days we want the simulation to be calculated. We wrote the parameters into a separated part of the table and referred to them in the model with cellreferences. For the optimalization of the parameters the MS Solver program were used, where conditions (validity limits) can also be defined.

\section{Comparison of simulation and monitoring on a coenological state-plane}

With the method described in the methodological subsection, a reference table from the daily coenological data of years with very different weather was established, from which, by applying NMDS, coordinates were ordered to the indicator organisms. The gained coordinates can be seen in Table 4. Later only these were used for the coenological state-planes. On the state-plane, coordinates of the samples were defined with the sum of the appropriate coordinates multiplied by the logarithms of individual numbers of indicator organisms.

Table 4. State-plane coordinates of the indicator organisms (indicator coordinates)

\begin{tabular}{lcc}
\hline \multicolumn{1}{c}{ Indicator organism } & X coordinate & Y coordinate \\
\hline Nepa cinerea adult & -0.258 & 0.105 \\
Nepa cinerea larva & 0.102 & 0.222 \\
Notonecta glauca adult & 0.116 & -0.492 \\
Notonecta glauca larva & -0.265 & 0.150 \\
Gerris lacustris adult & 0.384 & -0.150 \\
Gerris lacustris larva & 0.417 & -0.108 \\
Hydrometra stagnorum adult & -0.241 & 0.120 \\
Hydrometra stagnorum larva & -0.253 & 0.154 \\
\hline
\end{tabular}

Since the indicator coordinates are located around the origo (in all plane quarters) their weighted sum can be interpreted as linear combination of vectors pointing from the origo towards the indicator coordinates. Values of coenological coordinates characterising the sample are also influenced by the proportion and quantity of indicator organisms.

Coordinates of the coenological state-plane can be computed even to the empirical field monitoring data, and to the data which were simulated by the model from the daily mean temperatures of the same year. Thus the model and the empirical experience can be well compared.

\section{Case-study of the year 1996}

In Fig. 13, the empirical and simulation data from 1996 are displayed on coenologic state-plane. It can be well observed on the coenologic state-plane that the seasonal cycle appears on an elongated, oblong trajectory, with spring and autumn points positioned near to the origo, and midsummer points located on the furthest position from the origo in the right bottom plane quarter. The growing phase in the spring and the declining stage in the autumn runs differently, which meets expectations gained from former experiences (see subsection: Seasonal dynamic patterns represented by field data). Points from field 
samples are positioned around the model-trajectory, the two series of data fits well to each other. So, the model approaches reality quite well. In Figs. 14 and 15, simulated and empirical individual number logarithms of indicator organisms are even together and separatedly displayed. Comparing the seasonal patterns by species of the two figures, good accordance can be observed between the two series of data. Though a remarked difference is that the course of the curves of the model are simpler, and less hectic than the empirical series of data. It is quite conspicuous because the empirical series of data contain only weekly observations, while the model gives daily simulations. Thus, it can be stated that although the model shows the behaviour of the system, some of the disregarded interactions should be considered during the later development of the model.

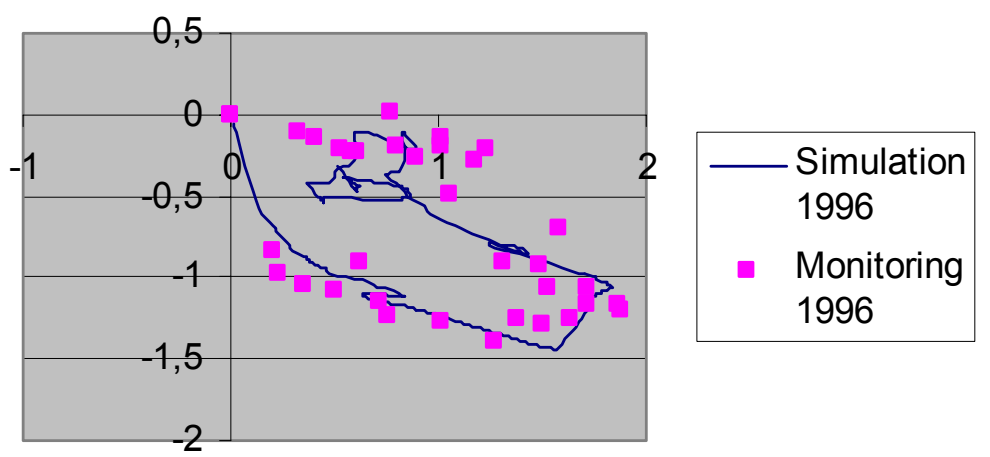

Figure 13. Comparison of field and simulated data on coenological state-plane (1996).

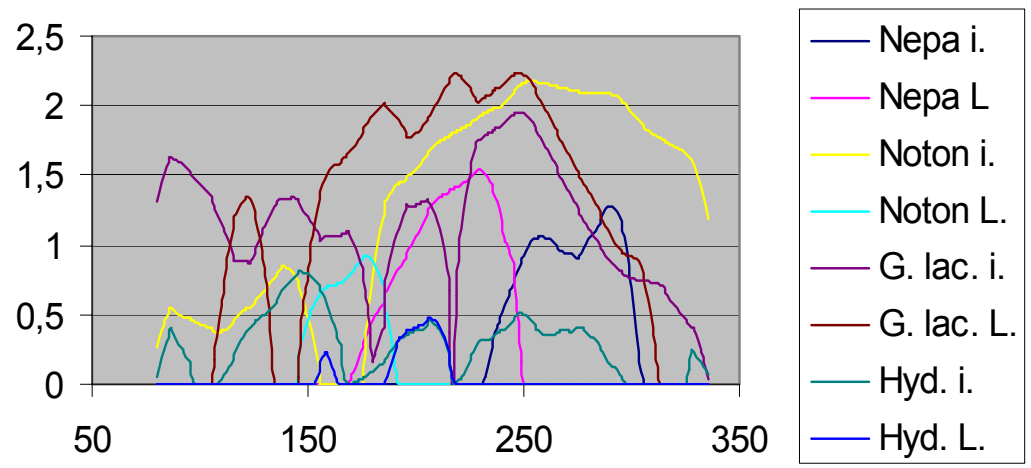

Figure 14. Simulated data of the individual number logarithms of indicator organisms (1996).

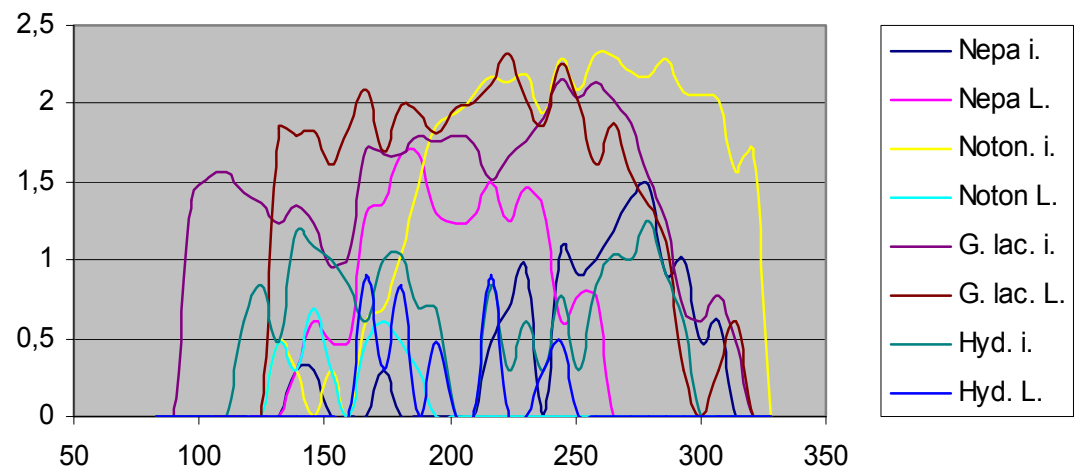

Figure 15.: Empirical data of the individual number logarithms of indicator organisms (1996). 
In Fig. 16, individual number logarithms from simulation and monitoring are displayed. Based on the figure, it can be stated that the model behaves realistically even in this respect, but processes of the field series of data run down faster and the model slightly underestimates the individual numbers in the growing phase.

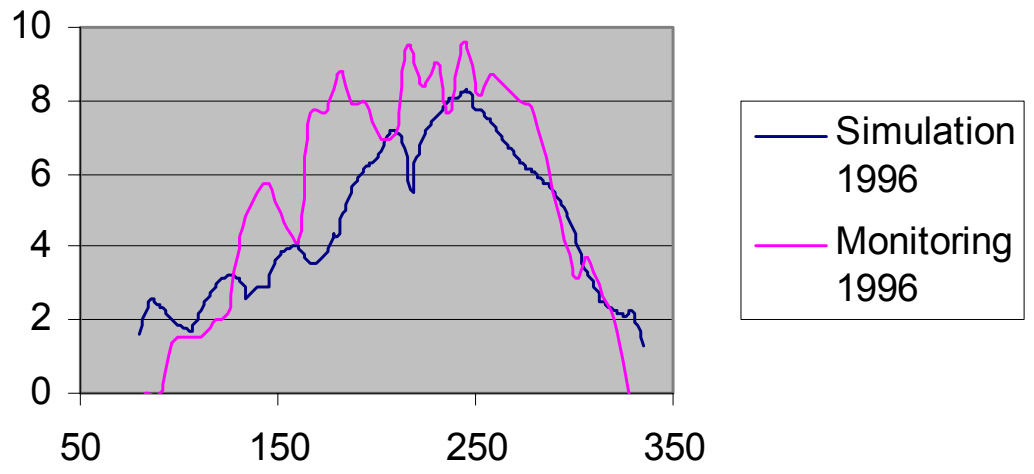

Figure 16. Sum of individual number logarithms of indicator species in case of 1996 empirical and simulated data.

\section{Climate change scenarios and the seasonal dynamic of the Heteroptera community}

An advantage of the simulation models is that they are capable of giving predictions to such kind of situations, which empirical examination is not possible. Before further developing the model, we considered to be practical to thoroughly examine how the model works under such weather circumstances which are basicly different from the kinds experienced here. Besides, these simulation experiments are also suitable for exploring by taking into consideration the known errors and validity limits of the model - the most possible scenarios of climate change. Obviously, (on our present level of knowledge) we do not have the possibility to forecast the future - even in the respect of the Heteroptera community on Szilas stream. However, it can be considered a realistic objective to examine the predictions of our model to realistic, hypothetical, or such kind of data series, which were generated by other models. This research objective fits into the goals of the VAHAVA project of the Hungarian Academy of Sciences, and also to the currently accepted main trend of the international climate change research [18, 32, 56, 100, 185].

To explore the possible effects of a future (such of unknown rundown) climate change, not real, but of realistic kind alternative scenarios, so-called climate-scenarios are needed. To clearly define the concept of climate change, we consider the following definition acceptable: „An inventory of future climates, which were made by using scientific principles, each of them is consistent - in itself - but none of them possesses a definite probability in accordance to which it shall take place "hence climatic scenario is only one of the possible climates and by no means prediction." [17, 55].

Recognizing the ecological problems of climatic change paved the way to the foundation of IPCC (Intergovernmental Panel on Climate Change) organisation (established by WMO - World Meteorological Organization - and UNEP), which aim is to give extensive and objective information about the scientific grounds and expected changes of a possible climatic change. During our work, we considered the principles determined by IPCC and used some of the internationally best accepted scenarios.

Climatic change scenarios which can be considered serious, are results of simulation models. For scenario generation, the so-called GCM-s, (General Circulation Model or Global Climate Model) are used. 
In the present paper, the GFDL2535 and GFDL5564 scenarios of the American Geophysical Fluid Dynamics Laboratory - which take the atmospheric $\mathrm{CO}_{2}$ rise into account, the BASE scenario - run with the current conditions, and the three very different scenarios of United Kingdom Meteorological Office (UKMO), namely UKHI (high resolution equilibrium climate change experiment), UKLO (low resolution equilibrium climate change experiment) and UKTR (high resolution transient climate change experiment) were used. The first two from the UKMOs three scenarios are so-called equilibrium models, which presumes the doubling of atmospheric $\mathrm{CO}_{2}$ and the models run until they get an equilibrium state of energy and stable surface temperature. UKTR is a so-called transient model, which examines the gradually changing climate by gradually growing atmospheric $\mathrm{CO}_{2}$ content $[18,81]$.

Rundown results of GCMs have to be scaled down to the given observation region with the use of empirical-statistical relations [32]. In this work, uniformly the $15^{\text {th }}$ running year of the 30-year-long models (applying to the period around 2050) were chosen. Its scaling down to the Hungarian region was made originally to the CLIVARA project (Climate Change, Climatic Variability and Agriculture in Europe). The necessary database and literature were provided by professor Zsolt Harnos, leader of the Hungarian project.

\section{Simulation experiment with the homogeneous manipulation of multiannual average of daily temperatures}

Before the examination of climatic change scenarios, we wanted to test the climatic sensitivity of the Heteroptera community model with simpler, easier to interpret, manipulated data series. In order to achieve this, the data series of multiannual average of daily temperatures were calculated, and by adding and subtracting $2{ }^{\circ} \mathrm{C}$, three different data series with identical shape but different values were gained.

In Figs. 17 and 18, the results simulated by the three data series are displayed. In Fig. 17 , change of state trajectories can also be seen on the coenological state-plane. The effect is powerful, and has a well-recognizable pattern. By the reduction of temperature, the trajectory elongates, by growing temperatures it widens compared to the main axis of the original trajectory.

In Fig. 18, the sum of individual number logarithms of the indicator organisms is displayed. Rising temperature causes growing density, while the decline renders the growing process steeper, so at the beginning of the stage is under the original values, and in the vicinity of the peak, it exceeds them. The three data series of temperature not only changed the magnitude of the values, but also altered the rundown of the curves.

Taking into account that according to former tests, the simulations of the model underestimated the individual numbers during a warm period, it is quite spectacular, to what extent individual numbers grow with the rise of temperature. If we consider the former experiences, we should think that a rise of temperature in reality would have an even greater impact than predicted by the model.

\section{Simulation experiment with scenarios of global atmospheric models scaled down to Hungarian regions}

Comparing the alternative climatic scenarios of the period around 2050 to the realistic meteorologic data series from the 1990's, the simulations conducted by the model show a marked difference even in respect of trajectories which can be observed on the coenological state-planes (Figs. 19 and 20), and even in respect of sum of individual number logarithms (Figure 21. and 22.). Simulated trajectories of scenario- 


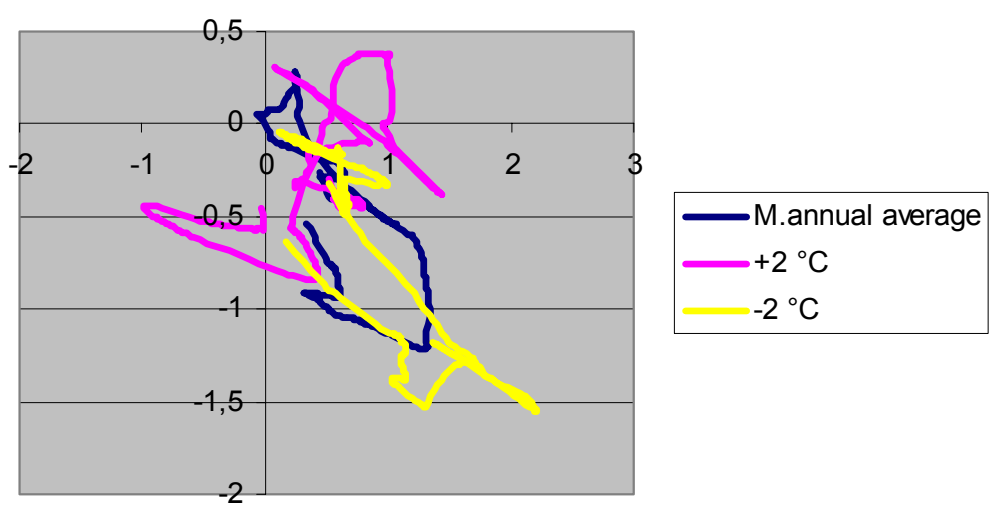

Figure 17. Simulated change of state trajectories gained by homogeneous modification of multiannual daily average temperatures on a coenological state-plane.

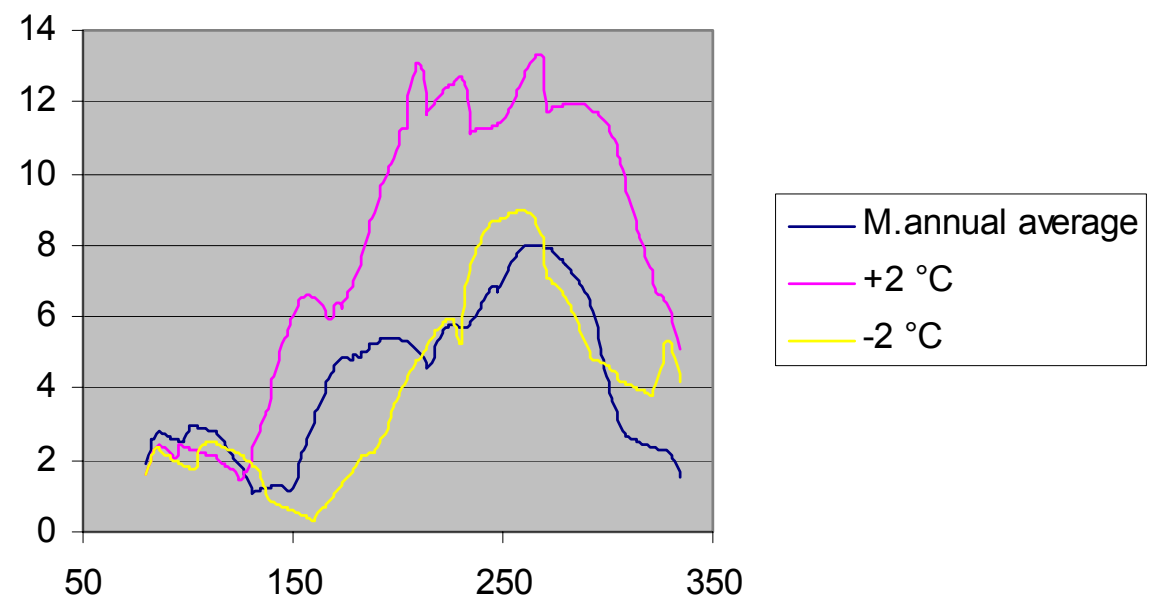

Figure 18. Sum of individual number logarithms of simulated data series gained by homogeneous modification of multiannual daily average temperatures on a coenological state-plane.

simulated data series show a much broader angle than the data from the ' 90 s. Broader angles refer to a greater change in individual numbers.

By observing Figs. 21 and 22, it can be stated that scenarios predict the growth of individual numbers and earlier position of peaks compared to simulations based on realistic data. Prediction of the BASE scenario stands nearest to the curves simulated by data from the 1990's. BASE scenario gives a prediction by presuming unchanged level of atmospheric $\mathrm{CO}_{2}$ (originally designed as control).

Simulation experiments by climatic scenarios pointed that the model designed for describing the seasonal-dynamic behaviour of Heteroptera indicator organisms is capable of giving appealing, well-interpretable realistic predictions by sensitively reacting for weather situations, which basicly differ from the ones which had been experienced during the validation of the model.

\section{Discussion}

In the community examined in this work - considering either only the Heteroptera, or the entire invertebrate species community - strong dominance of small number of 

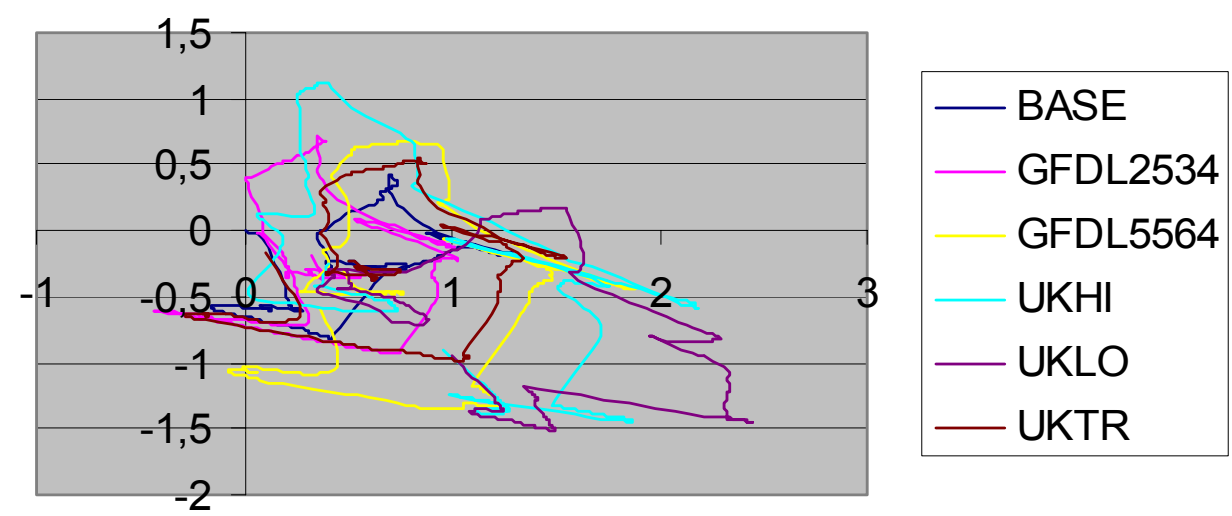

Figure 19. Expected rundown of trajectories of coenological change of states around 2050 by simulation based on different climatic change scenarios.
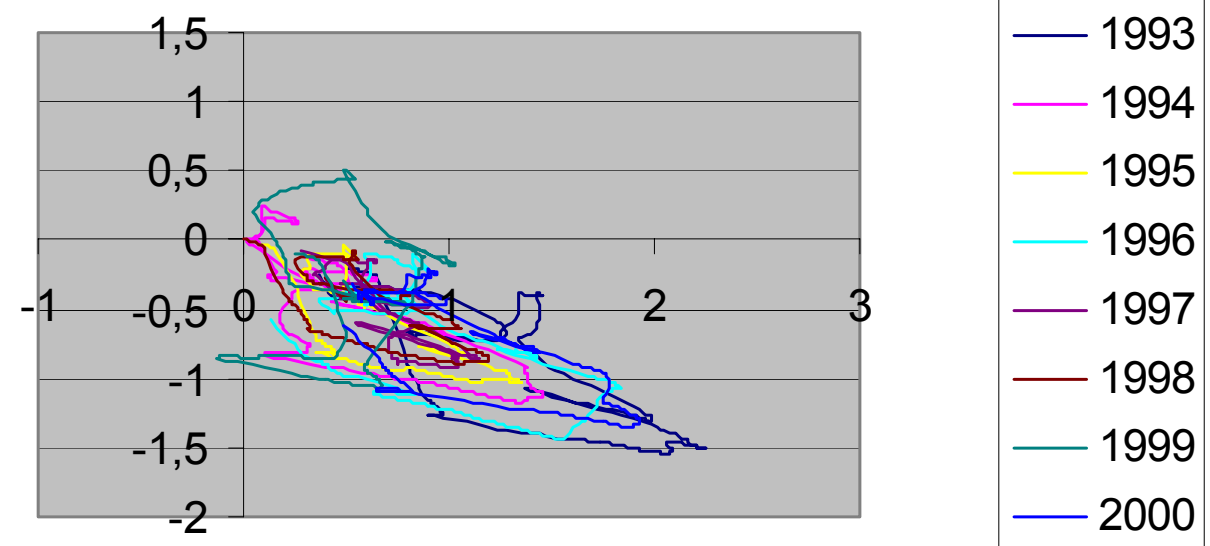

Figure 20. Rundown of trajectories of coenological change of states around 2050 by simulation based on real data series from the 1990s.

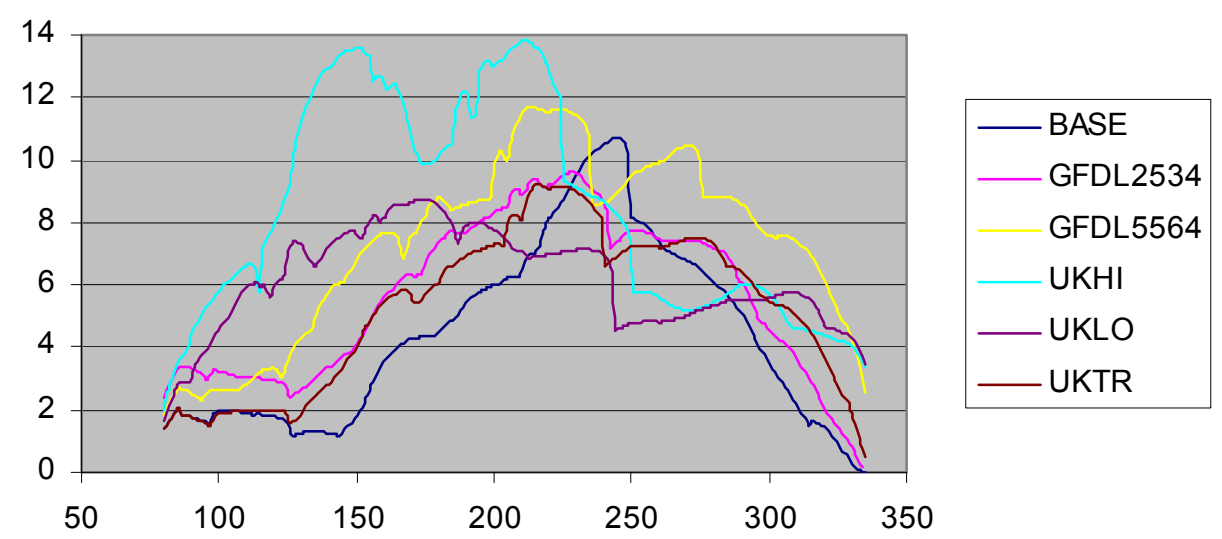

Figure 21. Expected rundown of sum of individual number logarithms around 2050 by simulation based on different climatic change scenarios.

dominant species can be observed beside the perceivable presence of relatively numerous species. In other aquatic habitats which we have examined, either a much lower number of species (and thus, low diversity) or much higher evenness beside approximately the same number of species (and thus, higher level of diversity) could be observed. The 


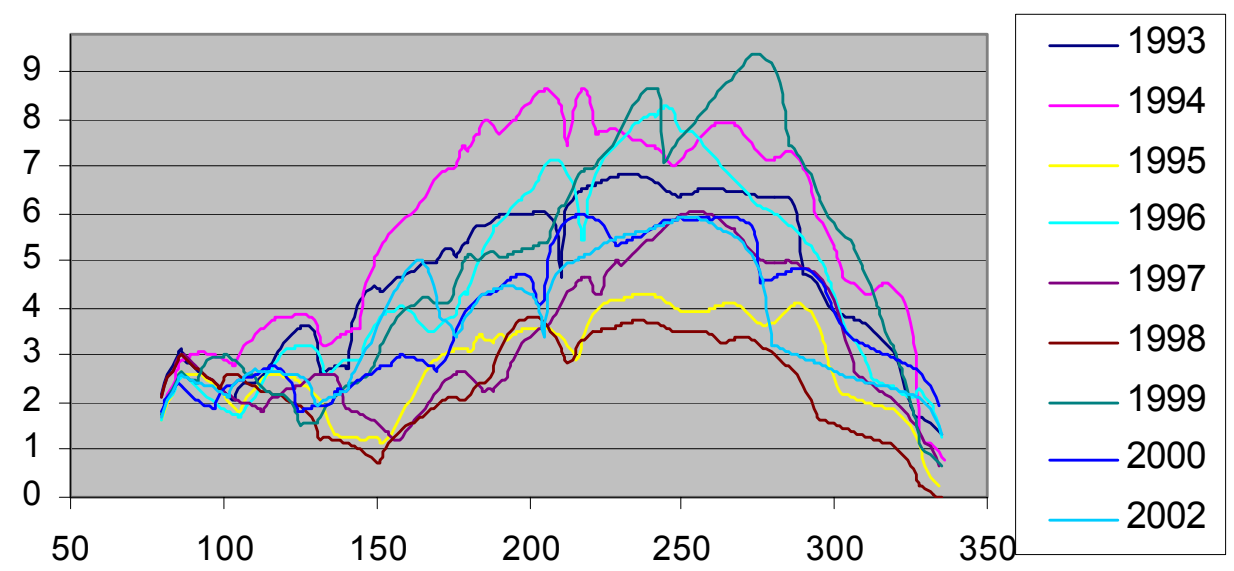

Figure 22. Expected rundown of sum of individual number logarithms around 2050 by simulation based on real data series from the 1990s.

reason for this presumably lies in the fact, that although this section of the Szilas stream can be considered a small current regarding its size, however it has a much greater hydrologic stability compared to other streams, which is mostly a feature of waters of greater size. A slight setback of the dominance of dominant species occurs approximately between the $150^{\text {th }}$ and $200^{\text {th }}$ day, when the species becoming more and more dominant during the year can not entirely exploit the disposable resources for historical reasons (delay in their prolification compared to ecological possibilities). In this period, level of diversity enhances, which is demostrated in the greater measurable number of species, and the lesser distributional unevenness. Later these species become gradually crowded out and even their lifecycle would not be always completed. For some species, the great number of migrating individuals is characteristic, this explains the ill-proportionedly great number of adults compared to the number of larvae.

The cyclic feature which is characteristic to the seasonal coenological change of state pattern of species communities, is probably determined primarily by the circaannual rundown of temperature. It is very improbable, that the rhythm in temperature and community structure would commence by the identical influence of a third, common factor. Thus, a direct cause and effect relation is presumed, though we could not prove it. A characteristic feature of the change of state pattern is - apart from its cyclic attribute - the appearance of aspects (similarity groups). The real reasons and ecological significance of this phenomenon is not meritably explored until now.

An important statement of this work is that based on the behaviour of a relatively small number of selected species the behaviour of the entire community can be assuringly predicted. Practically, this means that by monitoring a small number of indicator organisms, the change of state of the entire community may be surveyed. From our point of view, the high level of indicability of the seasonal patterns is an independent pattern-generating factor (presumably the temperature) which exerts the same effect on every population, and not by the cause and effect relations between the variables (e.g. population interactions).

Our hypothesis applying to the role of temperature is strengthened by the fact, that very resembling results can be simulated with a model which disregards all other outer abiotic factors and population interactions, despite it applies a very simple mathematical apparatus. 
Applicability of the stable state-planes based on indirect ordination is supported by the strong rules discussed above and the variable conditions which can be simulated by the model. The stable state-plane system is capable of effective dimension-reduction only in case when a broad spectrum of possible states is involved into the reference database which serves as a base for coordinates. For this, either many years of monitoring, or appropriate and realistic extension of the results of monitoring is needed. Appropriate extension of monitoring data can only be achieved by the application of suitable models.

This simulation model shows numerous imperfections, thus its further testing and developing is needed, which can be achieved during further field examinations and manipulative experiments. In its current form, the examined phenomenon is formally exact, but less accurate in predictions.

Combination of the simulation model of the Heteroptera community with climatic change models, provides a possibility to conduct a series of simulation experiments which applies to the near future (to the period around 2050). In this experiment, a comparison of the known weather data from the 1990's, and the alternative scenarios for the future take place.

Results of the simulation experiments predict a growth in the individual numbers of the dominant species of the Heteroptera community, and earlier occurrence of phenological phenomena for the case of Hungarian aquatic communities resembling to those examined on Szilas stream.

Available alternative scenarios of global atmospheric models - which are best accepted by the international scientific public opinion - describe the expected climatic change on our planet in very different ways. Thus, their predictions to the future are considered rather uncertain. However, in case we intend to analyse the effect of a possible climatic change to different communities and ecosystems, we do not have any other possibility as the application and development of simulation models. Considering the vast social significance and its characteristic to fundamentally determine our existence we think that even the most uncertain, however realistic prediction based on uncertain probability scenarios worths much more, than the entire lack of information, since this provides a possibility to create newer hypotheses and more careful consideration of the possibilities to counteract.

\section{Theses}

Research and development results of our work and the statements and methodical substances from the case studies can be summarized as listed below:

1. Between 1991 and 2002, on the investigated section of Szilas stream among the observed 57 Heteroptera species 42 are known to conduct a lifecycle which is to some degree tied to water, and among these only six species had dominance exceeding $1 \%$. From this six species, only four can be considered both in larva and adult stages as strictly constant elements. Thus, the Heteroptera community of Szilas stream can be characterised with great dominance of the constantdominant species in absolute terms.

2. The Gerris lacustris and Nepa cinerea populations on the observed area can be considered as autochtones. Specimens of the Notonecta glauca and Hydrometra stagnorum populations can be considered as of partially autochtone and partially allochtone origin.

3. It can be stated that the greater proportional appearance of non constantdominant species can be expected around the period of $150-200^{\text {th }}$ day, which is 
well before the appearance of the peak of the individual number of dominant species (generally around the $250^{\text {th }}$ day).

4. For the seasonal dynamics of the whole Heteroptera community, the annual cyclic feature is predominant which is manifested in the sampling dates similarity pattern. Typical pattern element is furthermore the grouping of the temporally close dates into aspects. Inside the aspects relatively slower, between the aspects faster coenological changes can be observed.

5. It can be stated, that the seasonal coenological similarity patterns displayed by the adults and larvae of the four constant-dominant species selected as indicator organisms greatly resemble to the dominant (non-Heteroptera) macroinvertebrate similarity patterns typical to Szilas stream. The two variable groups can be brought into strong canonical correlation with each other. Thus, the collective behaviour of the indicator organisms has significant predictive power and information content which can be applied for the whole community.

6. As a substance concerning the methodology of field monitoring it can be stated, that the seasonal-coenological sampling frequency in case of macroinvertebrates should take place at least fortnightly (or weekly) from the aspect of recognizability of changing of patterns. If sampling takes place less frequently, important pattern elements will remain hidden, or due to the rapid changes between aspects, even a false picture can be drawn if rare sampling is conducted in a period when intensive changes occur.

7. Based on data, total individual number of the community and the sliding average of average daily temperatures correlate with each other. Temporal course of indicators of temperature and community structure changes resemble to each other. Maximum of sum of total individual number of the community and logarithm of individual numbers generally takes place after the maximum of daily average temperatures, but the maximum of diversity indicators commences earlier.

8. Based on data series of daily average temperatures as input parameters, such a discrete-deterministic model can be drawn, which is able to generate textural (community structure) data series which resemble to the empirical data series. Thus, based on the change in temperature as a pattern-generating factor, empirical patterns become comprehensible. The constructed model can be fitted to the real data series - provided its parameters are in biologically acceptable ranges. Among circumstances which are quite different from the experienced the fitted model works stable and consequent and thus fulfils professional requirements.

9. The stable coenological state-plane which was constructed based on the principle of indirect ordination is suitable for unified handling of data series of monitoring and simulation, and also fits for their comparison. On the state-plane, such deviations of empirical and model-generated data can be seen, which could remain hidden based on the behaviour of conjugated indicators.

10. Significant differences can be observed in the course of trajectories and in the conjugated indicators by running the simulation model of Heteroptera communities first with the data series of climate change (UKMO and GFDL) scenarios applied for the period around 2050, scaled down for the area of Hungary which is most accepted internationally - and second by the data series of the 90's - which were tested by monitoring.

11. According to the predictions of the models by around 2050, drastic change in individual numbers can be expected - provided that other conditions of the 
hypothesis-system remain unchanged. Furthermore, the maximum of individual numbers will commence 20-50 days earlier than at present. Most of the applied climatic change scenarios count with the doubling of the aerial carbon-dioxide level. In case the carbon-dioxide level remains the same (BASE scenario), then by applying the computations of the global circulation model (GCM) and our Heteroptera coenological model, the circumstances around 2050 will resemble to the presently experienced figures.

Acknowledgements. Authors like to thank for everyone, who have been at their help during this research. They would like to thank especially to: Dr. Zsolt Harnos, Dr. Klára Dózsa-Farkas, Dr. János Balogh, Dr. Zoltán Mészáros, Márta Ladányi and Dr. Árpád Berczik. Special thanks to the colleagues of Budapest Corvinus University, Department of Mathematics and Informatics, to Eötvös Loránd University, Department of Zoosystematics and Ecology, Hungarian Academy of Sciences, Zootaxonomy (Soil Zoology) Research Group. Our work was financially supported by the NKFP 4/037/2001 and OTKA T042583 projects.

\section{REFERENCES}

[1] Allee W.C., Emerson, A.E., Park, O., Park, T. \& Schmidt, K.P. (1949): Principles of animal ecology. W.B. Saunders Co., Philadelphia and London.

[2] Allee, W.C. (1911): Seasonal succession in old forest ponds. - Tr. Ill. Acad. Sc. 4: 126131.

[3] Allee, W.C. (1932): Animal life and social growth - Williams \& Wilkins, Baltimore.

[4] Andersen, N.M. (1973): Seasonal polymorphism and developmental changes in organs of flight and reproduction in bivoltine pondskaters (Hem. Gerridae). - Entomologica Scandinavica 4: 1-20.

[5] Anonymous (1987): Az MTA ökológiai bizottságának állásfoglalása az ökológia néhány fogalmának definíciójáról. [Corporal statement of the Ecological Committee of the Hungarian Academy of Science on efinition of some concepts of ecology.] - Természet Világa 1987: 9. (www.vvt.gau.hu/ecology/mta.html).

[6] Aukema,B. \& Rieger, Ch. (eds.) (1995): Catalogue of the Heteroptera of the Palaearctic Region. Vol. 1. - The Netherl. Entomol. Soc., Amsterdam, xxvi+222 pp.

[7] Ayre, G.L. \& Lamb, R.J. (1990): Life histories flight patterns and relative abundance of nine cutworms Lepidoptera Noctuidae in Manitoba Canada. - Canadian Entomol. 122(11-12): 1059-1070.

[8] Bacchi, I., Rizzotti Vlach, M. \& Di Giovanni, M.V. (1996): Eterotteri acquaioli della Lombardia con particolare riguardo al popolamento delle risorgive (Insecta, Heteroptera), - Riv. Idrobiol. 35(1/2/3): 121-152.

[9] Bakonyi, G. (1977): Agrárökológiai vizsgálatok vízi élettérben, halkártevő Heteropterák alapján, Doktori értekezés. [Agro-ecological surveys in aquatic habitats, based on fishpest Heteroptera. Doctoral thesis.] GATE Gödöllö, 144 pp.

[10] Bakonyi, G., Csölle, C., Fabók, V., Földessy, M., Hufnagel, L., Kondorosy, E., Rédei, D., Tölgyesiné-Nell, T., Varga, I. \& Vásárhelyi, T. (2002): The Heteroptera fauna of the FertöHanság National Park. - In: The Fauna of the Fertö-Hanság National Park. Hungarian Natural History Museum, Budapest, pp. 325-350.

[11] Bakonyi, G. \& Vásárhelyi, T. (1981): Contribution to the Heteroptera fauna of the Hortobágy National Park. - In: The fauna of the Hortobágy National Park I. Akadémiai Kiadó, Budapest, pp. 55-63. 
[12] Bakonyi, G. \& Vásárhelyi, T. (1987): The Heteroptera fauna of the Kiskunsági National Park. - In: The fauna of the Kiskunság National Park II. Akadémiai Kiadó, Budapest, pp. 88-90.

[13] Bakonyi, G. \& Vásárhelyi, T. (1993a): Aquatic and semiaquatic bugs of the Bükk National Park (Heteroptera: Nepomorpha et Gerromorpha). - In: The fauna of the Bükk National Park. Hungarian Natural History Museum, Budapest.

[14] Bakonyi, G. \& Vásárhelyi, T. (1993b): Szakértöi tanulmány a Szigetköz akvatikus és szemiakvatikus poloskafaunájának vizsgálatáról az 1990-93 években. Kézirat. [Professional study on the survey of aquatic and semiaquatic Heteroptera fauna of Szigetköz. Manuscript.].

[15] Balogh, J. (1953): A zoocönológia alapjai. [Basics of zoocoenology.] Akadémiai Kiadó, Budapest.

[16] Balogh, J. (1958): Lebensgemeinschaften der Landtiere. Akademie-Verlag, Berlin.

[17] Barrow, E.M. (1993): Scenarios of climate change for the European Community. European Journal of Agronomy 2(4): 247-260.

[18] Barrow, E.M., Hulme, M., Semenov, M.A. \& Brooks, R.J. (2000): Climate change scenarios. - In: Downing, T.E. (ed.): Climate change, climatic variability and agriculture in Europe. Environmental Change Institute, University of Oxford.

[19] Benedek, P. (1970): The semiaquatic Heteroptera in the Carpathian Basin with notes on the distribution and the phenology of the species. - Faunistische Abhandlungen 6.

[20] Benedek, P. \& Jászai; V.E.: (1973): On the migration of Corixidae (Heteroptera) based on light trap data. - Acta Zool. Acad. Sci. Hung. 19: 1-9.

[21] Benedek, P. (1969): Poloskák VII. Heteroptera VII. - In: Fauna Hungariae 17: 1-86.

[22] Bhide, M. (1988): Seasonal variation in morphological, histopathological and histochemical changes on the median resorptive bodies (MRB) of Sphaerodema rusticum, Fabr. (Heteroptera). - J. Environ. Biol. 9(3): 219-229.

[23] Bíró, J. (2003): Temporal-spatial pattern of true bug assemblies (Heteroptera: Gerromorpha, Nepomorpha) in Lake Balaton - Applied Ecology and Environmental Research 1(1-2): 173181.

[24] Bíró, J. \& Hufnagel, L. (2001a): Bioindikáció Heteroptera közösségek alapján a Balaton vízrendszerében. [Bioindication based on Heteroptera communities in the water-system of Balaton.] - Hidrológiai Közlöny 81(5-6): 339-341.

[25] Bíró, J. \& Hufnagel, L. (2001b): Heteroptera fajok a Balaton vízrendszerében. [Heteroptera species in the water-system of Balaton.] - Folia Musei Historico-Naturalis Bakonyiensis 17: 111-118.

[26] Blashfield, R.K. \& Aldenderfer, M.S. (1978): The literature on cluster analysis. Multivar. Behav. Res. 13: 271-295.

[27] Blinn, D.W. \& Runck, C. (1989): Substratum reguirements for oviposition, seasonal egg densities, and conditions for egg eclosion in Ranatra montezuma (Heteroptera: Nepidae). - Ann. Entomol. Soc. Am. 82(6): 707-711.

[28] Borbás, V. (1879): Budapestnek és környékének növényzete. [Flora of Budapest and its surroundings.] Budapest.

[29] Brönmark, Ch., Malmqvist, B. \& Otto, Ch. (1985): Dynamics and structure of a Velia caprai (Heteroptera) population in a South Swedish stream. - Holarctic Ecology 8: 253-258.

[30] Bröring, U. \& Niedringhaus, R. (1988a): Die Verbreitung aquatischer und semiaquatischer Heteroptera (Hemiptera: Nepomorpha, Gerromorpha) auf Küstennahen Düneninseln der Nordesee. - Abh. Naturw. Verein Bremen 41(1): 7-16.

[31] Bröring, U. \& Niedringhaus, R. (1988b): Zur Ökologie aquatischer Heteroptera (Hemiptera: Nepomorpha) in Kleingewassern der ostfriesischen Insel Norderney - Arch. Hydrobiol. 111: 559-574.

[32] Butterfield, R.E., Bindi, M., Brooks, R.J., Carter, T.R., Delécolle, R. \& Downing, T.E. (2000): Review and comparison od scaling-up methods. - In: Downing, T.E. (ed.): 
Climate change, climatic variability and agriculture in Europe - Environmental Change Institute, University of Oxford.

[33] Clark, L.B. (1928): Seasonal distribution and life history of Notonecta undulata in the Winnipeg region, Canada. - Ecology 9: 383-403.

[34] Clements, F.E. (1916): Plant succession: an analysis of the development of vegetation. Publ. Carnegie Inst. Washington 242: 1-512.

[35] Clements, F.E. (1928): Plant succession and indicators; a definitive edition of plant succession and plant indicators. Wilson, New York.

[36] Cs. Halászfy, É. (1953): Bátorliget szipókás faunája. [The Rhynchota fauna of Bátorliget.] In: Székessy, V. (ed.): Bátorliget élővilága. Akadémiai Kiadó, Budapest, pp. 395-401. .

[37] Csörgits, G. \& Hufnagel, L. (2000a): Bioindikáció vízi gerinctelenekkel a Dunában. 4. Heteroptera fajegyüttesek hasonlósági mintázata a Dunán. [Bioindication with aquatic invertebrata in the Danube. Similarity pattern of Heteroptera communities in Danube.] Hidrológiai Közlöny 80(5-6): 288-290. .

[38] Csörgits, G. \& Hufnagel, L. (2000b): Heteroptera és Odonata fajegyüttesek a Nyéki-HoltDuna (DDNP) különböző hínár állományaiban. [Heteroptera and Odonata communities in different reed-grass sites on Nyéki-Holt-Duna (DDNP).] - Hidrológiai Közlöny 80(5-6): 291-294.

[39] Damgaard, J. \& Andersen, N.M. (1996): Distribution, phenology, and coservation status of the larger water striders in Denmark (Heteroptera: Gerridae). - Entomologiske meddelelser 64(4): 289-306.

[40] Dér, Zs, Rédei, D., Hufnagel, L. \& Pénzes, B. (2003): The effects of two cultivation methods on the Auchenorrhyncha and Heteroptera assemblages of raspberry plantations $4^{\text {th }}$ International Conference of PhD students (University of Miskolc), pp. 219-224.

[41] Dubois, R.B. \& Rackouski, M.L. (1992): Seasonal drift of Lethocerus americanus (Hemiptera: Belostomatidae) in a Lake Superior tributary. - Great Lakes Entomol 25(2): 85-89.

[42] Elton, Ch.S. (1927): Animal Ecology. Sidgwick and Jackson, London.

[43] Erdélyi, É. \& Hufnagel, L. (2003): A graph theory analyses of an agro-ecosystem. $-4^{\text {th }}$ International Conference of PhD students (University of Miskolc), pp 231-234.

[44] Eyre, M.D. \& Foster, G.N. (1989): A comparison of aquatic Heteroptera and Coleoptera communities as a basis for environmental and conservation assessments in static water sites. - J. Appl. Ent. 108: 355-362.

[45] Fahim, M.A., Hassanien, M.K. \& Mostafa, M.H. (2003): Relationships between climatic conditions and Potato Late Blight epidemic in Egypt during winter 1999-2001 - Applied Ecology and Environmental Research 1(1-2): 159-172.

[46] Fairbairn, D.J. (1985): Comparative ecology of Gerris remigis (Hemiptera: Gerridae) in two habitats: a paradox of habitat choice. - Canad. J. Zool. 63: 2594-2603.

[47] Földessy, M. (1988): A Mátra Múzeum Heteroptera gyüjteménye. [Heteroptera collection of Mátra Museum.] - Folia Hist.-nat. Mus. Matr. 13: 65-69. .

[48] Gaál M. \& Hufnagel L. (1999): Vízi élőhelyek állapotának monitorozása poloskaközösségek alapján. [Monitoring of aquatic habitats based on Heteroptera communities.] - In: Harnos, Zs. (ed.): Agrárinformatika 99 [Agroinformatics 99], Informatikai kutatások, fejlesztések és alkalmazások az agrárgazdaságban), konferencia kiadvány, Debreceni Agrártudományi Egyetem, Debrecen 346-350. .

[49] Gaál M. \& Hufnagel, L. (2000): Új módszerek az alkalmazott rovartani monitorozásban. [New methods in applied entomological monitoring.] - Lippay János \& Vas Károly Tudományos Ülésszak, Növényvédelmi Szekció összefoglalói, SZIE KTK, Budapest, pp. 382-383. .

[50] Gaál, M. \& Hufnagel, L. (2001): Combination of multivariate methods and graphical database management in service of ecological onitoring. - In: Steffe, J. (ed): EFITA 2001 Third European Conference of the European Federation for Information Technology in Agriculture, Food and the Environment, agroMontpellier ENSA, Montpellier, vol. 1, pp. 285-290. . 
[51] Gaál, M., Schmidtke, J., Rasch, D., Schmidt, K., Neemann, G. \& Karwas, M. (2004): Simulation experiments to evaluate the robustness of the construction of monitoring networks. - Applied Ecology and Environmental Research 2(2): 59-71.

[52] Gause, G.F. (1934): The struggle for existence. Williams and Wilkins, Baltimore.

[53] Green, D. (1990): Aquatic faunal communities and their fluctuations in adjacent ponds. Transactions of the Natural History Society of Northumbria 55(2): 97-135.

[54] Harada,T. \& Taneda, K. (1989): Seasonal changes in alary dimorphism of a water strider, Gerris paludum insularis (Motschulsky). - J. Insect Physiol. 35(12): 919-924.

[55] Harnos, N. (2003): A klímaváltozás hatásának szimulációs vizsgálata őszi búza produkciójára. [Simulation study on effects of climate change on the production of winter wheat.] - „Agro-21” Füzetek 31: 56-73. .

[56] Harnos, Zs., Bussay, A. \& Harnos, N. (2000): Modelling climate change impacts on wheat and potato in Hungary - In: Downing, T.E. (ed.): Climate change, climatic variability and agriculture in Europe. Environmental Change Institute, University of Oxford.

[57] Herodek, S. (1986): Phytoplancton changes during eutrophication and $\mathrm{P}$ and $\mathrm{N}$ metabolism. - In: Somlyódy, L. \& van Straten, G. (eds.) Modeling and managing shallow lake eutrophization. Springer Verlag, Berlin, pp. 183-204.

[58] Horváth, G. (1923). A Fertő-tónak és közvetlen környékének Hemiptera-faunája. [Hemiptera fauna of Fertö-Lake and its immediate surroundings.] - Annales Musei Nationalis Hungarici 20: 182-199. .

[59] Horváth, G. (1931). A Balaton vizében és viztükrén élő hemipterák. [Aquatic and semiaquatic Hemiptera of Balaton.] - A Magyar Biol. Kut. Int. I. Osztályának munkáiból 4: 1-5.

[60] Horváth, L., Hufnagel, L., Révész, A., Gaál, M., Ladányi, M. \& Erdélyi, É. (2002): Agroökoszisztémák modellezése. [Modelling of agro-ecosystems.] - In: Palkovics, M. \& Kondorosyné-Varga E. (eds.): XLIV. Georgikon Napok: Stabilitás és intézményrendszer az agrárgazdaságban (konferencia kiadvány), Georgikon, Keszthely, p. 45.

[61] Horváth, L., Gaál, M. \& Hufnagel, L. (2003): Modelling of spatio-temporal patterns of ecosystems in agricultural fields. - In: Harnos, Zs. et al. (eds.): EFITA 2003 Information technology for a better agri-food sector, environment and rural living, Proceedings of EFITA 2003 Conference, Debrecen-Budapest, Hungary, pp. 882-889.

[62] Hufnagel, L. (1994): Adatok a Naplás-tó és környéke élővilágához III. A Naplás-tó és környéke vízi és vízfelszíni poloskafaunája. [Data for the flora and fauna of Naplás-Lake and its surroundings.] - Calandrella, 8(1-2): 94-102. .

[63] Hufnagel, L. (1997): Une nouvelle espece d'Hétéroptere pour la Faune de France: Paracorixa concinna (Fieber, 1848) (Heteroptera: Corixidae). - Bulletin de la Société entomologique de France 102(4): 384.

[64] Hufnagel, L. (1998a): Note rectificative a ma publication „Une nouvelle espece d'Hétéroptere pour la Faune de France: Paracorixa concinna (Fieber, 1848) (Heteroptera: Corixidae)" - Bulletin de la Société entomologique de France 103(3): 228.

[65] Hufnagel, L. (1998b): Data to the knowledge of the aquatic, semiaquatic and shore bug fauna of Budapest and the county Pest (Heteroptera: Nepomorpha, Gerromorpha, Leptopodomorpha). - Folia entomologica hungarica 59: 29-34.

[66] Hufnagel, L. (1998c): Faunánkra új partipoloskafaj. [New shore bug species to the fauna of Hungary: Salda muelleri (Gmelin, 1790) (Heteroptera, Saldidae)]. - Folia entomologica hungarica 59: 273-274.

[67] Hufnagel, L. (2000a): Új cönológiai állapotleíró módszerek a rovartani monitorozásban. Doktori értekezés. [New coenological description methods in ecological monitoring. Doctoral thesis.] Szent István Egyetem.

[68] Hufnagel, L. (2000b): A water strider species new to the fauna of Afghanistan: Gerris asper (Fieber, 1860) (Heteroptera: Gerromorpha) - Opuscula Zoologica 32: 169-170.

[69] Hufnagel, L. (2000c): Bevezetés a folyóvíz-ökológiába. [Introduction to the ecology of water currents.] - In: Dukay, I. (ed.): Kézikönyv az élővizek vizsgálatához. Göncöl Alapítvány és Szövetség, Vác. 
[70] Hufnagel, L., Mészáros, Z. Gaál, M. \& Ferenczy, A. (1999a): Temporal spatial patterns of Noctuinae communities (Lep. Noctuidae) in Hungarian apple orchards (Apple Ecosystem Research). - Acta Phytopathologica et Entomologica Hungarica 34(4): 341-353.

[71] Hufnagel, L., Gaál, M., Ferenczy, A. \& Öszi, B. (1999b): Többváltozós módszerek alkalmazása rovaregyüttesek tér-időbeli zoocönológiai monitorozásában. [Application of multivariate methods in spatio-temporal zoocoenological monitoring of insect communities.] In: Csirik, J. \& Herdon, M. (eds.): Informatika a felsőoktatásban. Debreceni Egyetemi Szövetség, Debrecen, vol. 1, pp. 215-220.

[72] Hufnagel, L., Bakonyi, G. \& Vásárhelyi, T. (1999c): New approach for habitat characterization based on species list of aquatic and semiaquatic bugs. - Environmental Monitoring and Assessment 58: 305-316.

[73] Hufnagel, L., Bakonyi,G. \& Vásárhelyi,T. (1999d): Sokváltozós módszerek alkalmazása vízi és vízfelszíni poloskákra épülő vízminősítési rendszerekben. [Application of multivariate methods in water-qualification systems based on aquatic and semiaquatic Heteroptera]. - Állattani Közlemények 84: 29-41.

[74] Hufnagel, L. \& Stollmayer, B.E. (1999): Zoocoenological pattern of bug assemblies (Heteroptera: Nepomorpha, Gerromorpha, Leptopodomorpha) in the Szilas and Gyáli streams. - Opuscula Zoologica 31: 69-77.

[75] Hufnagel, L. \& Mészáros, Z. (1999): Populációdinamikai stabilitás a növényvédelmi prognosztika szolgálatában. Population dynamic stability in the service of plant protection prognostics.] - In: Sáringer Gy. et al. (eds.): 45. Növényvédelmi Tudományos Napok [ $45^{\text {th }}$ Plant Protection Days] konferenciakötet. RePrint Kft., Budapest, p. 56.

[76] Hufnagel, L. \& Vásárhelyi, T. (2000): On the larvae of Cymatia rogenhoferi (Fieber, 1864) and Gerris asper (Fieber, 1860). - Annales Historico-Naturales Musei Nationalis Hungarici 91: 61-63. .

[77] Hufnagel, L., Csörgits, G. \& Bíró, J. (2000): Biodiverzitás mérésének problémái vízirovarok fajegyütteseiben. [Problems of measuring biodiversity of aquatic insect communities.] - Hidrológiai Közlöny 80(5-6): 306-308. .

[78] Hufnagel, L., Gaál, M., Öszi, B., Mészáros, Z. (2001): Population dynamical stability in service of plant protectional prognosis. - Acta Phytopathologia et Entomologia Hungarica 36: 93-99.

[79] Hufnagel, L. \& Gaál, M. (2002): Indirekt ordináció módszere és alkalmazása az ökológiai monitorozásban. [Method and application of indirect ordination in ecological monitoring.] 6. Magyar Biometriai és Biomatematikai Konferencia, Szent István Egyetem, Budapest, pp. $30-31$. .

[80] Hufnagel, L. \& Gaál, M. (2002): Többváltozós állapotsíkrendszerek alkalmazása valós és szimulált adatsorok kezelésében. [Application of multivariate state-plane systems in handling of real and simulated data series.] - In: Harnos, Zs. (ed.): Agrárinformatika 2002 [Agroinformatics 2002], konferencia kiadvány. Debreceni Agrártudományi Egyetem, Debrecen.

[81] IPCC (1996): Climate change (1995): The science of climate change. Cambridge University Press, Cambridge.

[82] Jansson, A. (1969): Identification of larval Corixidae (Heteroptera) of Northern Europe. Annales Zool. Fennici 6: 289-312.

[83] Jansson, A. (1986): The Corixidae (Heteroptera) of Europe and some adjacent regions. Acta Entomol. Fenn. 47: 1-94.

[84] Jansson, A. (1987): Micronectinae (Heteroptera, Corixidae) as indicators of water quality in Lake Vesijarvi, southern Finland, during the period of 1976-1986. - Biol. Res. Rep. Univ. Jyvaskyla 10: 119-128.

[85] Jebanesan, A., Selvanayagam, M. (1994): Population dynamics of aquatic hemipterans in the river Cooum, Madras. - Journal of Environmental Biology 15(3): 213-220. 
[86] Jeyanthi, M. \& Venkatesan, P. (1997): Population dynamics of the aquatic bug, Diplonychus indicus Venk. \& Rao, a bioagent in mosguito breeding pond. - Journal of Entomological Reserach 21(1): 17-23.

[87] Jordán, F. (2003): Comparability: the key to the applicability of food web research. Applied Ecology and Environmental Research 1(1-2): 1-18.

[88] Juhász-Nagy, P. (1984): Beszélgetések az ökológiáról. [Conversations on ecology.] Mezőgazdasági Kiadó, Budapest.

[89] Juhász-Nagy, P. (1986): Egy operatív ökológia hiánya, szükséglete és feladatai. [Lack, needs and tasks of an operative ecology.] Akadémiai Kiadó, Budapest, 251 pp.

[90] Juhász-Nagy, P. (1993): Az eltünő sokféleség. (A bioszféra-kutatás egy központi kérdése). [Disappearing diversity.] Scientia Kiadó, Budapest. .

[91] Kaiser, M. (1970): Budapest XVI. kerületi Mátyásföld alkalmazott geomorfológiai térképlap magyarázója. [Guide to the applied geomorphologic map of Mátyásföld, Budapest XVI. district.] Manuscript. MÁFI adattár.

[92] Kaitala, A. (1987): Dynamic life-history strategy of the waterstrider Gerris thoracicus as an adaptation to food and habitat variation. - Oikos 48(2): 125-131.

[93] Kalivoda, B. (1986): Adatok Budapest északkeleti részének madárvilágáról. [Data on bird fauna of the northeastern part of Budapest.] - Madártani Tájékoztató 1986(1-3): 27-35. .

[94] Kharkwal, G., Mehrotra, P., Rawat, Y.S. \& Pangtey, Y.P.S. (2004): Comparative study of herb layer diversity in pine forest stands at different altitudes of Central Himalaya. Applied Ecology and Environmental Research 2(2): 15-24.

[95] Kumar, A. (1996): Seasonal variations in the calorific contents of certain predatory insects in a village frish pond of Santhal Parganas (Bihar). - Journal of Environmental Biology 17(1): 59-62.

[96] Ladányi, M., Gaál. M., Horváth, L., Hufnagel, L., Révész, A. \& Erdélyi, É. (2003a): An agro-ecosystem simulation model for precision agriculture. - In: Werner, A. \& Jarfe, A. (ed.): Programme book of the joint conference of ECPA-ECPLF. Wageningen Academic Publishers, The Netherlands, pp. 469-470.

[97] Ladányi, M., Horváth, L., Gaál, M. \& Hufnagel, L. (2003b): An agro-ecological simulation model system - Applied Ecology and Environmental Research 1(1-2): 47-74.

[98] Ladányi, M. \& Hufnagel, L. (2003a): Fenológiától függő egyedszám meghatározás. [Individual number measurement depending on phenology.] - In: Lippay János-Ormos Imre-Vas Károly Tudományos Ülésszak összefoglalói, pp. 46-47.

[99] Ladányi, M. \& Hufnagel, L. (2003b): A phenology model embedded in an ecosystem model for agroecological processes. - In: Harnos, Zs. et al. (eds.): EFITA 2003 Information technology for a better agri-food sector, environment and rural living. Proceedings of EFITA 2003 Conference, Debrecen-Budapest, Hungary, pp. 876-881.

[100] Láng, I. (2003): Bevezető gondolatok „A globális klímaváltozással összefüggő hazai hatások és az arra adandó válaszok" címü MTA-KvVM közös kutatási projekthez. [Introductory concepts: Domestic effects of the global climate change and counteractions.] - „Agro21" Füzetek 31: 3-8. .

[101] Lindeman, R.L. (1941): Seasonal food-cycle dynamics in a senescent lake. - Am. Mid. Nat. 26: 636-673.

[102] Lindeman, R.L. (1942): The trophic-dynamic aspect of ecology. - Ecology 23: 399-418.

[103] López, T., Costas, M. \& Vázquez, M.Á. (1996): Fenología y estadios juveniles de Sigara (Sigara) janssoni Lucas, 1983 (Heteroptera: Corixidae) - Boln. Asoc. Esp. Ent. 20(3-4): 19-29.

[104] Lotka, A.J. (1925): Elements of physical biology. Williams \& Wilkins, Baltimore.

[105] Lovelock, J.E. (1987): Gaia. Oxford University Press, Oxford.

[106] Macan, T. (1938): Evolution of aquatic habitats with special reference to the distribution of Corixidae. - J. Animal Ecol. 7: 1-19.

[107] Macan, T. (1954): A contribution to the study of the ecology of Corixidae (Hemiptera). J. Animal Ecol. 23: 115-141. 
[108] Macan, T. (1965): A revised key to the British aquatic bugs. Scientific Publications of the FBA No. 16, 74 pp.

[109] Majer, J. (1993): Az ökológia alapjai. [Basics of ecology.] Szaktudás Kiadó, Budapest.

[110] Marosi, S. \& Somogyi, S. (eds.) (1990): Magyarország kistájainak katasztere I-II. [Catastral survey of the small regions of Hungary.] MTA Földrajztudományi Kutatóintézet, Budapest.

[111] McPherson, J.E. (1988): Life history of Mesovelia mulsanti (Hemiptera: Mesoveliidae) in southern Illinois. - Great Lakes Entomol 21(1): 19-23.

[112] McPherson, J.E. \& Packauskas R.J. (1986): Life history and laboratory rearing of Belostoma lutarium (Heteroptera, Belostomatidae), with descriptions of immature stages. - Journal N.Y. ent. Soc. 94(2): 154-162.

[113] McPherson, J.E., Packauskas, R.J., Korch, P.P. (1987): Life history and laboratory rearingof Pelocoris femoratus (Hemiptera, Naucoridae), with descriptions of immature stages. - Proceding ent. Soc. Wash. 89(2) : 288-295.

[114] McPherson, J.E. (1986): Life history of Neoplea striola (Hemiptera:Pleidae). - Great Lakes Ent. 19(4): 217-220.

[115] Mehrotra, P., Kharakwl, G. \& Pangety, Y.P.S. (2004): Ecological implication of plant traits, strategies and competitive abilities of herbs. - Applied Ecology and Environmental Research 2(2): 1-13.

[116] Mironga, J.M. (2004): Geographic Information Systems (GIS) and remote sensing in the management of shallow tropical lakes - Applied Ecology and Environmental Research 2(1): 83-103.

[117] Miura,T. \& Takahashi, R. (1987): Predation of Microvelia pulchella (Hemiptera: Veliidae) on mosquito larvae. - J. Am. Mosquito Contr. Assoc. 3: 91-93.

[118] Móczár, L. (ed.) (1982): Állathatározó. [Animal identification.] Tankönyvkiadó, Budapest, vols. 1-2.

[119] Moldoványi, L. (1977): Adatok a Hortobágyi vizek poloskafaunájának ismeretéhez (Heteroptera). [Data for the Heteroptera fauna of aquatic habitats on Hortobágy.] - Folia entomologica hungarica 30: 2.

[120] Moldoványi, L. (1984): Faunisztikai vizsgálatok a Rakaca tározó poloskáin (Heteroptera). [Faunistical studies on the Heteroptera of Rakaca water storage cistern.] - Folia entomologica hungarica 45(1): 231-235.

[121] Møller-Andersen, N (1982): The semiaquatic bugs. - Entomonograph 3: 1-455.

[122] Muraji, M., Miura,T. \& Nakasuji, F. (1989): Phenological studies on the wing dimorphism of a semi-aquatic bug Microvelia douglasi (Heteroptera: Veliidae). - Res. Pop. Ecol. 31: 129-138.

[123] Muraji, M., Miura, T. \& Nakasuji, F (1991): Seasonal occurrence and habitat utilization of semiaquatic bugs, Microvelia spp. (Heteroptera. Veliidae). - Acta Sericol. Entomol. 4: 75-83.

[124] Muraji, M., Miura, T. \& Nakasuji, F. (1989): Change in photoperiodic sensivity during hibernation in a semiaquatic bug Microvelia douglasi (Heteroptera, Veliidae). - Appl. Entomol. Zool. 24(4): 450-457.

[125] Murray, A.M. \& Giller, P.S. (1990): The life-history of Aquarius najas de Geer (Hemiptera, Gerridae) in Southern Ireland. - Entomologist 109(1): 53-64.

[126] Nowinszky, L. (2004): Nocturnal illumination and night flying insects. - Applied Ecology and Environmental Research 2(1): 17-52.

[127] Nummelin, M., Vepsäläinen, K. \& Spence, J.R. (1984): Habitat partitioning among developmental stages of waterstiders (Heteroptera: Gerridae). - Oikos 42: 267-275.

[128] Nummelin, M. (1997): Wing dimorphism of the water strider Limnogonus franciscanus (Stål) (Heteroptera: Gerridae) in a seasonal tropical climate. - Entomologica Fennica 8(3): 167-170.

[129] Nyilas, L., Hufnagel, L., Gaál., M, Mészáros, Z. (2000): Noctuidae fajegyüttes szezonális és szukcesszív dinamikája a Julianna-majori fénycsapda adatainak tükrében. [Seasonal and successive dynaimes of a Noctuidae community in he wake of ligh-trap data from 
Julianna-grange.] - Lippay János \& Vas Károly Tudományos Ülésszak 2000, Növényvédelmi Szekció összefoglalói, SZIE KTK, Budapest, pp. 426-427.

[130] Okada, H. \& Nakasuji, F. (1993): Comparative studies on the seasonal occurrence, nymphal development and food menu in two giant water bugs, Diplonychus japonicus and D. major (Hem. Belostomatidae) - Researches on Population Ecology (Kyoto) 35(1): 15-22.

[131] Oscarson, H.G. (1987): Habitat segregation in a water boatman (Corixidae) assemblage the role of predation. - Oikos 49(2): 133-140.

[132] Öszi, B., Hufnagel, L. \& Mészáros, Z. (2000): Szezonális dinamikai mintázatok és modellezésük a platánfa-csipkéspoloska (Corythucha ciliata Say, Tingidae) példáján. [Seasonal dinamical patterns and their modelling on the example of Corythucha ciliata.] Lippay János \& Vas Károly Tudományos Ülésszak 2000, Növényvédelmi Szekció összefoglalói, SZIE KTK, Budapest, pp. 432-433.

[133] Packauskas, R.J. \& McPherson, J.E. (1986): Life history and laboratory rearing of Ranatra fusca (Hemiptera: Nepidae), with descriptions of immature stages. - Annals. ent. Soc. Am. 79(4): 566-571.

[134] Pajunen, V.I. \& Jansson A. (1969): Seasonal changes in the sex ratio of rock pool corixids. - Ann. Zool. Fennici 6: 219-226.

[135] Pandit, S., Adhikary, S. \& Roy S. (1994): Seasonal changes of some limnological factors in the River Damodar and their impact on aquatic insects. - Environment and Ecology 12(3): 501-506.

[136] Pandit,S., Adhikary S. \& Roy, S. (1996): Population dinamics and diversity of hemipteran insects three different sites of the River Damodar in West Bengal. - Environment and Ecology 14(4): 810-814.

[137] Pandit, S., Adhikary, S. \& Mondal, S. (1993): Seasonal changes of some limnological factors in the river Damodar with special emphasis on the population dinamics of aquatic insects 2. Hemiptera and Odonata. - Journal of Freshwater Biology 5(49): 305-313.

[138] Papp, L. (ed.) (1997): Zootaxonómia. [Zootaxonomy.] Magyar Természettudományi Múzeum, Budapest.

[139] Patel, S.R., Awasthi, A.K. \& Tomar, R.K.S. (2004): Assessment of yield losses in mustard (Brassica juncea L.) due to mustard aphid (Lipaphis erysimi Kalt.) under different thermal environments in Eastern Central India - Applied Ecology and Environmental Research 2(1): 1-15.

[140] Pécsi, M., Marosi, S. \& Szilárd, J. (1958): Budapest természeti képe. [Natural scape of Budapest.] Akadémiai Kiadó, Budapest.

[141] Pécsi, M., Marosi, S. \& Szilárd, J. (1959): Budapest természeti földrajza. [Nature geography of Budapest.] Akadémiai Kiadó, Budapest.

[142] Péricart, J. (1990): Hémipteres Saldidae et Leptopodidae d'Europe occidentale et du Maghreb. - In: Fauna de France 77. Fédér. Francaise Soc. Sci. Nat., pp. 1-238.

[143] Podani, J. (1993a): SYN-TAX Version 5.0 Users Guide. Scientia, Budapest, 104 pp.

[144] Podani, J. (1993b): SYN-TAX. Computer programs for multivariate data analysis in ecology and systematics. - Abstracta Botanica 17(1-2): 289-302.

[145] Podani, J. (1994): Multivariate analysis in ecology and systematics. SPB Publishing, The Hague.

[146] Podani, J. (1997): Bevezetés a többváltozós biológiai adatfeltárás rejtelmeibe. [Introduction into the secrets of multivariate data exploration.] Scientia, Budapest.

[147] Précsényi, I. (1995): Alapvető kutatásszervezési, statisztikai és projectértékelési módszerek a szupraindividuális biológiában. [Elementary research arranging, statistical and project evaluation methods in supraindividual biology.] KLTE, Debrecen.

[148] Rajkai, K. (1975): A Szilas-patak egyes réti fitocönózisai és gyakorlati jelentőségük. [Individual meadow phytoceonoses Szilas stream and their pratical significance] Botanikai Közlemények 62: 203-215.

[149] Rajkai, K. (1979): Újabb adatok a Szilas-patak réti fitocönózisairól. [New data on meadow phytocoenoses of Szilas stream.] - Botanikai Közlemények 66: 205-212.. 
[150] Rédei, D., Gaál, M. \& Hufnagel L. (2003a): Spatial and temporal patterns of true bug assemblages extracted with Berlese funnels (Data to the knowledge on the ground-living Heteroptera of Hungary, No. 2) - Applied Ecology and Environmental Research 1(1-2): 115-142.

[151] Rédei, D., Gaál, M. \& Hufnagel, L. (2003b): Információnyerés szórványos adatsorokból „bootstrap” módszerrel - egy esettanulmány. [Getting information from sporadic data using bootstrap method - a case study.] - In: Lippay János-Ormos Imre-Vas Károly Tudományos Ülésszak összefoglalói, pp. 52-53.

[152] Rédei, D., Harmat, B. \& Hufnagel, L. (2004): Ecology of the Acalypta species occuring in Hungary (Insecta: Heteroptera: Tingidae) (Data to the knowledge on the ground-living Heteroptera of Hungary, № 3) - Applied Ecology and Environmental Research 2(2): 73-90.

[153] Rédei, D. \& Hufnagel L. (2002a): Beitrage zur Kenntnis der Dipsocoromorpha-Arten (Insecta: Heteroptera) in Ungarn. - Opuscula Zoologica 34: 67-76.

[154] Rédei, D. \& Hufnagel L. (2002b): Eremocoris abietis (Linnaeus, 1758), eine für die Fauna Ungarns neue Wanze (Insecta: Heteroptera). - Opuscula Zoologica 34: 131.

[155] Rédei, D. \& Hufnagel L. (2003a): The species composition of true bug assemblages extracted with Berlese funnels (Data to the knowlwdge on the ground-living Heteroptera of Hungary, No. 1) - Applied Ecology and Environmental Research 1(1-2): 93-114.

[156] Rédei, D. \& Hufnagel L. (2003b): Adatok a Dunántúli-középhegység talajlakó poloskafaunájának ismeretéhez (Heteroptera). [Data to the knowledge on the soil bug fauna of the Hungarian Transdanubian-Mountains (Heteroptera).] -Folia Musei Historico-Naturalis Bakonyiensis 20: 63-76.

[157] Rédei, D.; Hufnagel, L. (2003c): Adatok az Északi-középhegység talajlakó poloskafaunájának ismeretéhez (Heteroptera). [Data to the knowledge on the soil bug fauna of the Hungarian Northern-Mountains (Heteroptera).] - Folia historico naturalia Musei Matraensis 27: 81-89.

[158] Reissig, W.H., Heinrichs, E.A., Litsinger, J.A., Moody, K., Faedler, L., Maw, T.W. \& Bergen, A.T. (1985): Illustrated guide of integrated pest management in rice in tropical Asia. - Int. Rice Res. Inst. , Los Banos, Laguna, Philippines, 441 pp.

[159] Rifaat H.M. \& Yosery, M.A. (2004): Identification and characterization of rubber degrading Actinobacteria. - Applied Ecology and Environmental Research 2(1): 63-70.

[160] Roy, S.P. \& Sharma, U.P. (1982): Investigations on the abundance and seasonality of corixids (Corixidae: Hemiptera) in a freshwater pond of Bhagalpur (Bihar). - Journal biol. Res. $2(1): 44-47$.

[161] Savage, A. (1982): Use of water boatmen (Corixidae) in the classification of lakes. Biol. Conservation 23: 55-70.

[162] Savage, A. (1990): The distribution of Corixidae in lakes and the ecological status of the Nord West Midland Meres. - Field Studies 7: 516-530.

[163] Savage, A. (1994): Corixidae and the water quality. - Freshwater Forum 4: 214-216.

[164] Savage, A. (1994): The distribution of Corixidae in relation to the water quality of British lakes: a monitoring model. - Freshwater Forum 4: 32-61.

[165] Savage, A. \& Pratt, N.N. (1976): Corixidae (water boatmen) of the Nord West Midland Meres. - Field Studies 4: 465-476.

[166] Savage, A. (1989): Adults of the British aquatic Hemiptera: key with ecological notes. FBA No. 50, 173 pp.

[167] Schmera, D. (2001): A Halesus digitatus (Schrank 1781) tegzes faj (Insecta: Trichoptera) repülés aktivitás mintázatai. [Flight activity pattern of the Halesus digitatus trichopteran species.] - Hidrológiai Közlöny 81(5-6): 457-458.

[168] Schmera, D. (2002): Seasonal change of light trap-collected caddisfly (Insecta: Trichoptera) fauna of the Börzsöny Mountains (Northern Hungary) with reference to the effect of air temperature on the succes of light trapping. - Lauterbornia 44: 65-73.

[169] Schmidt, S. (1893): Czinkota geológiai viszonyairól. [Geological characteristics of Czinkota.] - Földtani Közlöny 33: 329-342. 
[170] Selvanayagam, M. \& Raghunatha Rao, T.K (1986): Wing polymorphism in five species of gerrids from south India (Heteroptera: Gerridae). - J. Curr. Biosci. 3(2): 61-71.

[171] Shokri, M., Safaian, N., Ahmadi, M.Z.T. \& Amiri, B.J. (2004): A second look on Biogeographical Province of Miankaleh Biosphere Reserve - Applied Ecology and Environmental Research 2(1): 105-107.

[172] Sládecek, V. \& Sládecková, A. (1994): Corixidae as indicators of organic pollution. Freshwater Forum 4: 211-213.

[173] Soós, Á (1977): Veränderungen der Wasserhemipterenfauna des Velenceer-Sees durch menschliche Einwirkungen. - Verh. VII. Int. Symp. Entomofaunistik in Mitteleuropa, pp. $143-146$.

[174] Soós, Á. (1958): Felhasználható-e a múzeumok rovaranyaga ökológiai vizsgálatokra? [Are the insect collections of museums suitable for ecological studies?] - Állattani közlemények 46(3-4): 277-285.

[175] Soós, Á. (1963): Poloskák VIII. Heteroptera VIII. - In: Fauna Hungariae 17: 1-48.

[176] Spellerberg, I.F. (1991): Monitoring ecological change. Cambridge University Press, Cambridge.

[177] Spence, J.R. (1981): Experimental analysis of microhabitat selection in water-striders (Heteroptera: Gerridae). - Ecology 62(6): 1505-1514.

[178] Spence, J.R. (1983): Pattern and process in co-existence of water-striders (Heteroptera: Gerridae). - J. Anim. Ecol. 52: 497-511.

[179] Spence, J.R. (1989): The habitat templet and life history strategies of pond skaters (Heteroptera: Gerridae): reproductive potential, phenology, and wing dimorphism. - Can. J. Zool. 67(10): 2432-2447.

[180] Stollmayerné, B.E., Kecskés, F., Ócsag, A., Bognár, A., Puky, M. \& Bódi, L. (1991): Adatok a Naplás-tó és környéke élővilágához. [Data for the flora and fauna of Naplás-Lake and its surroundings.] - Calandrella 5(1): 65-84.

[181] Štusák, J.M. (1980): Rád Plostice - Heteroptera. - In: Rozkosky, R. (ed.): Keys to aquatic larvae of insects. Ceskoslovenska Akad. Ved., Praha, pp. 133-155.

[182] Tamás, J. (2003): Problems and solutions of field scale agro-ecological data acquisition and data interpretations in agroinformatical domain. - Applied Ecology and Environmental Research, 1(1-2): 143-157.

[183] Varga, I. \& Hufnagel, L. (2001): Temporal-spatial patterns of aquatic and semi-aquatic Heteroptera (Gerromorpha, Nepomorpha) at Lake Fertő, Hungary. - Opuscula Zoologica 33: 99-112.

[184] Varga, I., Andrikovics, S. \& Hufnagel, L. (1999): New data for macrofauna of Lake Fertő. - Opuscula Zoologica 31: 143-148.

[185] Varga-Haszonits, Z. (2003): Az éghajlatváltozás mezőgazdasági hatásának elemzése, éghajlati szcenáriók. [Analysis of climate change effects on agriculture, climate scenarios.] - „Agro-21” Füzetek 31: 9-28.

[186] Vargha, K. (1990): Budapest vizeiben élő akvatikus és szemiakvatikus poloskafauna vizsgálata. [Survey of aquatic and semiaquatic Heteroptera fauna living in Budapest waters.] ELTE TFK Szakdolgozat, pp 53.

[187] Vásárhelyi, T. (1975): Adatok Magyarország karimáspoloskáinak ismeretéhez (Heteroptera: Coreidae). [Data to the knowledge on Hungarian coreids.] - Folia entomologica hungarica 29(1): 139-145.

[188] Vásárhelyi, T. (1990): Family-key to the larvae of true bugs of Hungary. - Fol. entomol. hung. 51: 149-161.

[189] Vásárhelyi, T. (1995): A nádasok állatvilága. [Fauna of reeds.] Hungarian. Natural History Museum, Budapest, 199 pp.

[190] Vásárhelyi, T. (1985): A Barcsi borókás poloskafaunájának alapvetése (Heteroptera). [First study on the heteropteran fauna of the juniper grove at Barcs]. - In: Dunántúli Dolgozatok Természettudományi Sorozat 5: 101-104. 
[191] Vásárhelyi, T. (1989): Microhabitat preference of the pondweed bug Mesovelia furcata (Het: Mesoveliidae). - Fol. Entomol. Hung. 50: 165-168.

[192] Vásárhelyi, T. \& Bakonyi, G. (1987): A Balaton vizén és víztükrén élö poloskák (Heteroptera). [Aquatic and semiaquatic Heteroptera of Balaton.] - Folia entomologica hungarica 49: 240-241.

[193] Vásárhelyi, T. \& Hufnagel, L. (1990): A platánfa légies átka. [Aerial curse of plane trees.] - Élet és Tudomány 45(30): 940-942.

[194] Vásárhelyi, T., Kondorosy, E. \& Bakonyi, G. (1990): The Heteroptera fauna of the Bátorliget Nature Reserves. - In: The Bátorliget Nature Reserves after forty years. Hungarian Natural History Museum, Budapest, pp. 347-355.

[195] Vásárhelyi,T., Dobos, Zs., Gál, I., Halácsy, Á., Halbritter, A., Hufnagel, L., Munkácsi, Zs. \& Pataki, Zs. (1995): Vízben és vízfelszinen élő poloskák határozókulcsa. [Identification key to aquatic and semiaquatic Heteroptera.] - Módszertani Lapok (Biológia) 1(3): 19-23.

[196] Vepsäläinen, K. \& Krajewski, S. (1986): Identification of the waterstrider (Gerridae) nymphs of the Northern Europe. - Annales Entomologica Fennici 52: 63-77.

[197] Vepsäläinen, K. (1974): The wing lenghts, reproductive stages and habitats of Hungarian Gerris Fabr. species (Heteroptera, Gerridae). - Ann. Acad. Sci. Fenn., Biologica 202: 1-18.

[198] Vepsäläinen, K. \& Nummelin, M. (1986): Habitat selection by waterstrider larvae (Heteroptera: Gerridae) in relation to food and imagoes. - Oikos 47: 374-381.

[199] Voltera, V. (1926): Variazioni e fluttuazioni del numero d'individui in specie animali conviventi. - Mem. Accad. Lincei 6(2): 31-113.

[200] Voltera, V. (1931): Variation and fluctuations of the number of individuals in animal species living together. - In: Chapman, R.N. (ed.) (1931): Animal ecology. McGraw-Hill, New York.

[201] Zera, A.J. (1985): Wing polymorphism in waterstriders (Gerridae: Hemiptera): mechanism of morph determination and fitness differences between morphs. - Contrib. Mar. Sci. 27 (Suppl.): 674-686.

[202] Zimmermann, M. (1984): Population structure, life cycle and habitat of the pondweed bug Mesovelia furcata (Hemiptera, Mesoveliidae). - Revue suisse Zool. 91(4): 1017-1035. 